Review

\title{
Sustainable Coatings on Metallic Alloys as a Nowadays Challenge
}

\author{
Radu Nartita ${ }^{1}$ (D), Daniela Ionita ${ }^{1, *(D)}$ and Ioana Demetrescu $1,2, *$ (D) \\ 1 Department of General Chemistry, Faculty of Applied Chemistry and Material Science, \\ University Politehnica of Bucharest, 313 Splaiul Independentei, 060042 Bucharest, Romania; \\ nartita.radu@gmail.com \\ 2 Academy of Romanian Scientists, Ilfov Street, 3, 050044 Bucharest, Romania \\ * Correspondence: daniela.ionita@upb.ro (D.I.); i_demetrescu@chim.upb.ro (I.D.)
}

Citation: Nartita, R.; Ionita, D.; Demetrescu, I. Sustainable Coatings on Metallic Alloys as a Nowadays Challenge. Sustainability 2021, 13, 10217. https://doi.org/10.3390/ su131810217

Academic Editor: Mariateresa Lettier

Received: 22 August 2021

Accepted: 10 September 2021

Published: 13 September 2021

Publisher's Note: MDPI stays neutral with regard to jurisdictional claims in published maps and institutional affiliations.

Copyright: (c) 2021 by the authors. Licensee MDPI, Basel, Switzerland. This article is an open access article distributed under the terms and conditions of the Creative Commons Attribution (CC BY) license (https:// creativecommons.org/licenses/by/ $4.0 /)$.

\begin{abstract}
Starting with a description of the meaning of sustainable coating nowadays, this review presents a selection of methods for sustainable coatings manufacture using raw materials, saving energy and costs. This selection creates an introduction for the coatings performances of intensively investigated coated alloys and their multifunctionality. There are many examples and EU recommendations to be discussed, and we especially chose to introduce sustainable coatings with both industrial and medical functions, such as bioinspired films and coatings on high-entropy alloys, biodegradable metallic alloys, etc. A special focus is on nanotechnology and nanomaterials in green procedures, enhancing coatings' multifunctionality, introducing green corrosion inhibitors, smart additives, and coatings based on superhydrophobicity. The conclusions and future perspectives of sustainable and multifunctional coatings, as expressions of sustainable advanced materials, are based on important motivations of such studies.
\end{abstract}

Keywords: sustainable coatings; metallic alloys; green procedures

\section{Introduction}

At the end of the last century and the beginning of the new one, the concept of enhancing materials properties only at the surface, as an economic way of increasing quality, was leading to a large number of procedures for surface modifications, including all kinds of coatings at the micro- and nano-level [1-6].

In the last decade, the dynamic development in industrial [7] and biomedical fields has been very aggressive, looking for more and more speed and performance of materials behavior in their service life. In this context, it is mandatory to keep in mind the future of our planet. Avoiding the depletion of natural resources, finding greener industrial processes, and maintaining an ecological balance became a challenge for all of us. All researchers also have a duty to share the knowledge in this domain, as a part of the sustainability of their strategy. As is well known, article 3 of the Treaty of European Union is a commitment to a 'high level of protection and improvement of the quality of the environment' [8].

In general, any sustainable product design is based on multiple inter-connected principles [9], as shown in Figure 1.

Sustainable materials refer to materials with a relatively positive impact on the environment, and they are used for product fabrication and service delivery [3]. The selection of sustainable materials depends both on objective and subjective factors, and several models have been proposed for their design [10]. The research in this field, with the help of nanotechnology [11], has been intensively extended in the last years, and a great part, such as in the building construction domain [12], has been transferred successfully into economic production quickly. Sustainable coatings have the general characteristics of sustainable materials that have a reduced negative impact on the environment, providing 
a chance for recycling and reduced elaboration costs, while maintaining the performances. An expression of this commitment in the field of coatings is of interest for bioinspired protections [13,14], green corrosion inhibitors [15,16], smart additives [17,18], etc.

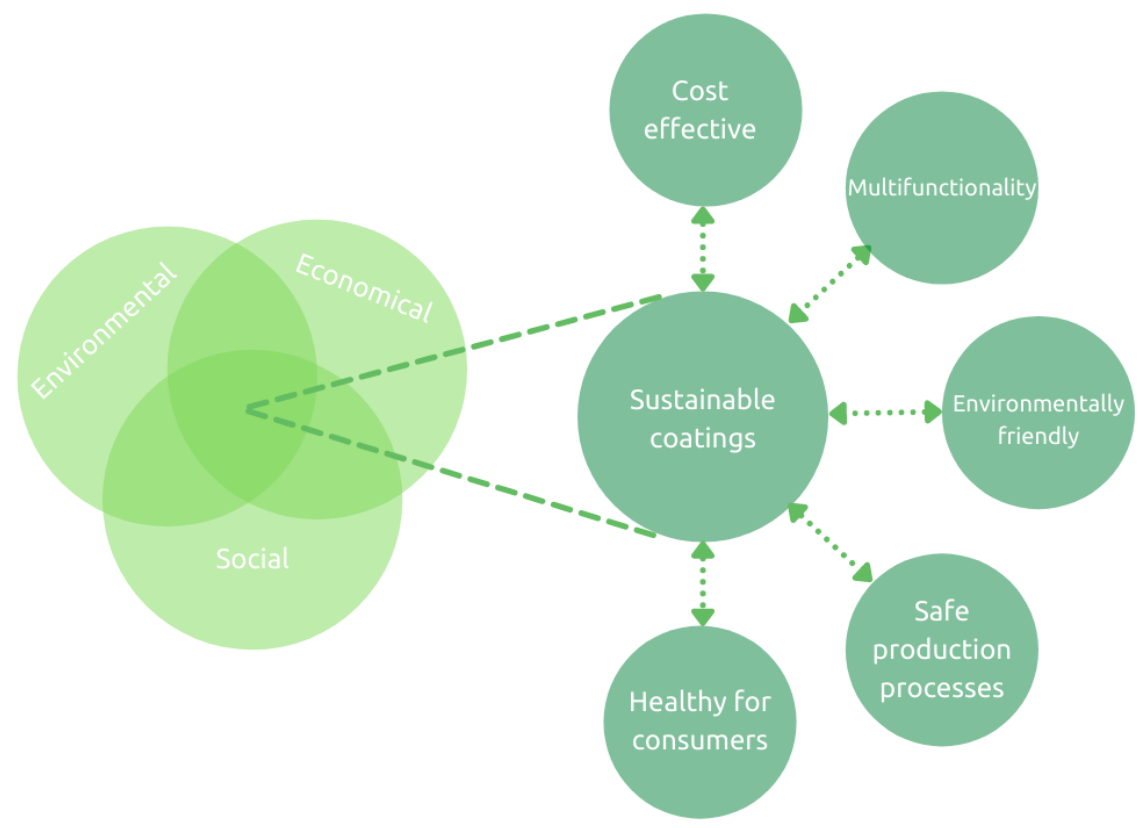

Figure 1. Schematic depiction of sustainable coatings based on the three pillars of sustainability.

The sustainability of coatings is characterized by the use of materials with multiple functionalities, while employing methods that minimize the waste, have low prices, pose little threat to humans, and save energy and resources [19]. Considering these highly complex factors, it is clear that a line between sustainable and non-sustainable processes cannot be drawn, but the principle aspects have been discussed and outlined, and therefore everyone must assess and improve. The latest regulations imposed by the governmental policies are forcing industries, as well as consumers, to find more sustainable, environmentally friendly approaches [20]. The multifunctional coatings sustain the materials and energy savings, serving different applications [21-23], for example, interesting research that addresses the current waste of millions of tons of fruits and vegetables, caused by decay, promotes an edible coating consisting of non-toxic zinc oxide nanoparticles with diameters between 10 and $40 \mathrm{~nm}$, chitosan, and Arabic gum [24]. Another sustainable coating consisting of a thin layer of yttrium-doped zinc oxide-cadmium oxide on a glass substrate was proposed for the detection of $\mathrm{CO}_{2}$. The sol-gel spin method used is a low-cost method that does not require much energy consumption or high amounts of chemicals [25].

The aim of this manuscript, and its novelty, is to present the challenges in sustainable coatings on metallic alloys research, regarding the trends in enhancing multifunctionality and performances using more environmentally friendly procedures $[14,26]$.

In the present conditions of aggressive climate change [27], a narrative review with identified objectives about sustainable coatings, for more protection and future perspectives, is necessary. Although it is impossible to say which coating is better, we hope that through our review research, we may identify multiple sustainable methods that can be employed simultaneously to create a sustainable coating that may be further escalated in the industry, and ultimately improve the quality of life.

\section{Methods}

The safe-by-design (SbD) concept implementation aims at obtaining safer materials and products, safer use of products and safer industrial production. Compared to the older approach, which focused on measures applied retroactively, this approach would ideally 
be employed in the first steps of development, rather than once the process is started. However, improvements in reducing the risk for humans and the environment can still be achieved even in the later stages [28-30].

As an example, in a company that used pure silicon nanoparticles to increase the performance of batteries, the $\mathrm{SbD}$ concept implementation helped in lowering the toxicity threat for the workers, as well as lowering the risk of explosion, while achieving higher stability and performance. To do so, the nanoparticles' size was increased from $40 \mathrm{~nm}$ to $75 \mathrm{~nm}$ to reduce the alveolar deposition and the nanoparticles were coated with amorphous carbon, which led to increased performance and lower risk of explosion $[29,31]$.

\subsection{Methods in the Present Narrative Review Elaboration}

We aim to present, through this review, important trends and challenges in sustainable coatings development, in the present conditions. We also try to objectively analyze the current research conducted in the area of functional coatings on metallic alloys and highlight the practices that promote sustainability.

The selection of the discussed articles is based on the current trends, their novelty and relevance to this review. It is important to mention that over 150 records were identified through multiple searches and screened for this summary.

\subsection{Methods for the Development of Sustainable Coatings}

The traditional manufacturing techniques, machining and casting, are generating a large amount of waste materials. Therefore, to achieve environmental sustainability researchers have begun to pay more attention to other methods, such as laser cladding, producing functional coatings with improved properties, while reducing the waste material and improving the costs associated [32-37]. The cold spray process has also been proposed as a sustainable, versatile method that can be used with various substrates for multiple applications. Although copper and aluminum were mostly used as coating materials, ceramic coatings, cobalt, nickel, iron or organic coatings can also be achieved [38].

A topic that is becoming more frequently discussed and studied is that of superhydrophobic surfaces. This is mainly due to the possible extensive applications, such as anti-icing, anti-corrosion, anti-fogging and self-cleaning coatings. This interesting property has been firstly observed in nature, in lotus leaves, rice leaves and butterfly wings. Although the fluorinated compounds are useful in creating this type of coating and have been used, they may be harmful to the environment, having bioaccumulative and toxic effects. Therefore, researchers moved towards non-fluorinated compounds that can manifest the same characteristics. These surfaces can be fabricated through multiple sustainable methods, such as spray coating, spin coating, dip coating, grafting method and vapor deposition method [39,40].

In many industrial processes, an important step is the purification of organic solvents from mixtures with water. Coatings may help as well in the case of azeotropic or near azeotropic mixtures, where the conventional separation methods require high energy consumption, besides having low efficiency. Considering the sustainability principles, a zeolite-based membrane, highly water-selective was constructed on an aluminum oxide support through wet gel conversion, using small quantities of gel and no organic matrix [41]. Another coating, based on the antifouling properties of zwitterions, has been used on stainless steel mesh by immersing the substrate in a copolymer solution. The copolymer used was a combination between dopamine methacrylamide (DMA) and a zwitterionic monomer, 2-methacryloyloxyethylphosphocholine (MPC). The coating has proved to be very efficient, separating the water from a mixture with n-hexane with an efficiency above $97 \%$ [42].

\section{Trends in Enhancing Coatings Performances on CoCr Alloys and Other Metallic Alloys (Including High-Entropy Alloys)}

There are several alloys with low density, resistance to corrosion, and reduced ion release in a large number of environments, as well as good mechanical behavior for a large 
temperature domain. These properties recommend alloys such as stainless steel, $\mathrm{CoCr}$, aluminum, magnesium, and titanium alloys, also depending on other factors, namely, thermal and electrical properties, wear, stability, and processing costs, to be used in various industrial applications and the medical field [43-48].

Of course, for a specific application, each alloy has a different performance and the struggle for more efficiency in advanced technologies has introduced surface modifications, including coatings for more safety and more functionality in the service life. In Table 1, we present a summary of some alloys with different applications, before and after being coated, to highlight the improvements that a coating can bring. Some of the values reported here were approximated, as they were read on the figures available.

Table 1. Comparison between the properties of some uncoated and coated alloys.

\begin{tabular}{|c|c|c|c|c|c|}
\hline Alloy & Coating & Parameter & Uncoated Alloy & Coated Alloy & Ref. \\
\hline 45 steel & FeNiCoCrTi0.5Nb0.5 & Hardness (HV) & 852 & 294 & [49] \\
\hline \multirow{3}{*}{ Q235 steel } & \multirow{3}{*}{$\mathrm{CoCr}_{2.5} \mathrm{FeNi}_{2} \mathrm{Ti}$} & $\begin{array}{l}I_{\text {corr in simulated saturated salty }} \\
\text { water solution }\left(\mu \mathrm{A} \mathrm{m}^{-2}\right)\end{array}$ & $4.531 \times 10^{-4}$ & $1.386 \times 10^{-4}$ & \multirow{3}{*}{ [35] } \\
\hline & & Microhardness (HV) & 192 & 450 & \\
\hline & & Wear weight loss (mg) & 5.8 & 3.2 & \\
\hline \multirow{4}{*}{ Ti64 } & \multirow{4}{*}{$\mathrm{Ti} 64+\mathrm{CoCr}$} & Porosity $(\%)$ & 0.9 & 3.2 & \multirow{4}{*}{ [50] } \\
\hline & & Hardness (HV) & 360 & 430 & \\
\hline & & Friction coefficient $\mu$ & 0.56 & 0.8 & \\
\hline & & Wear rate $\left(\times 10^{-4} \mathrm{~mm}^{3} / \mathrm{Nm}\right)$ & 7.9 & 1.7 & \\
\hline \multirow{2}{*}{ Zircaloy-4 } & \multirow{2}{*}{$\mathrm{ZrSi}_{2}$} & Pool boiling $\left(\mathrm{kW} / \mathrm{m}^{2}\right)$ & 858 & 813 & \multirow{2}{*}{ [51] } \\
\hline & & Leidenfrost temperature $\left({ }^{\circ} \mathrm{C}\right)$ & 300 & 345 & \\
\hline \multirow{3}{*}{ Ti-6Al-4V } & \multirow{3}{*}{$\mathrm{Ti}$} & Microhardness (HV) & 332.7 & 433.8 & \multirow{3}{*}{ [52] } \\
\hline & & Wear volume $\left(\mathrm{mm}^{3}\right)$ & 0.08 & 0.02 & \\
\hline & & Wear width $(\mu \mathrm{m})$ & 1.96 & 1.52 & \\
\hline \multirow{4}{*}{$\mathrm{TiNbZr}$} & \multirow{4}{*}{$\begin{array}{l}\text { Pectin/polypyrrole } \\
\text { loaded with } \\
\text { gentamicin }\end{array}$} & $\begin{array}{l}\text { I }_{\text {corr }} \text { in simulated body fluid (SBF) } \\
\left(\mu \mathrm{A} \mathrm{cm}^{-2}\right)\end{array}$ & $1.715 \times 10^{-2}$ & $0.032 \times 10^{-2}$ & \multirow{4}{*}{ [53] } \\
\hline & & Growth inhibition (\%)—S. Aureus & $\begin{array}{l}\text { No antibacterial } \\
\text { activity }\end{array}$ & 86.82 & \\
\hline & & $\begin{array}{c}\text { Growth inhibition }(\%)-P . \\
\text { Aeruginosa }\end{array}$ & $\begin{array}{l}\text { No antibacterial } \\
\text { activity }\end{array}$ & 80.00 & \\
\hline & & Cell density (a.u.) & 0.55 & 0.75 & \\
\hline \multirow{5}{*}{$\mathrm{Ti}-5 \mathrm{Cu}$} & \multirow{5}{*}{$\mathrm{TiO}_{2} / \mathrm{Cu}_{2} \mathrm{O}$} & Contact angle $\left(^{\circ}\right)$ & 61 & 18 & \multirow{5}{*}{ [54] } \\
\hline & & Surface roughness $(\mu \mathrm{m})$ & 0.221 & 0.427 & \\
\hline & & $\mathrm{I}_{\text {corr }}$ in $0.9 \% \mathrm{NaCl}\left(\mu \mathrm{A} \mathrm{cm}^{-2}\right)$ & $1.85 \times 10^{-7}$ & $0.47 \times 10^{-7}$ & \\
\hline & & $\begin{array}{l}\text { Corrosion resistance of the inner } \\
\text { layer }\left(\mathrm{M} \Omega \mathrm{cm}^{2}\right)\end{array}$ & 3.52 & 4.86 & \\
\hline & & Antibacterial rate on S. aureus (\%) & $83.4 \%$ & $>99 \%$ & \\
\hline \multirow{3}{*}{$\mathrm{CoCr}$} & \multirow{3}{*}{$\mathrm{TiO}_{2}-\mathrm{Ag}$} & Wear $(\mu \mathrm{m})$ & 20 & 5 & \multirow{3}{*}{ [55] } \\
\hline & & Wear loss (mg) & 0.3 & 0.1 & \\
\hline & & Frictional force $(\mathrm{N})$ & 1.85 & 0.94 & \\
\hline
\end{tabular}


Table 1. Cont.

\begin{tabular}{|c|c|c|c|c|c|}
\hline Alloy & Coating & Parameter & Uncoated Alloy & Coated Alloy & Ref. \\
\hline \multirow{6}{*}{$\mathrm{CoCr}$} & \multirow{6}{*}{$\mathrm{Nb}-\mathrm{Ta}$} & Surface roughness $(\mu \mathrm{m})$ & 1.16 & 3.49 & \multirow{6}{*}[56]{} \\
\hline & & Contact angle $\left(^{\circ}\right)$ & 90 & 120 & \\
\hline & & Microhardness (HV) & 500 & 800 & \\
\hline & & $\mathrm{I}_{\text {corr }}$ in Ringer's solution $\left(\mu \mathrm{A} \mathrm{cm}^{-2}\right)$ & 3.03 & 0.369 & \\
\hline & & MTS cell proliferation (absorbance) & 0.23 & 0.39 & \\
\hline & & Hemolysis ratio $(\%)$ & 4.8 & 3.11 & \\
\hline \multirow{2}{*}{$\mathrm{CoCr}$} & \multirow{2}{*}{ TiSiON } & Friction coefficient $\mu$ & 0.34 & 0.06 & \multirow{2}{*}{ [57] } \\
\hline & & Wear rate $\mathrm{K}\left(\times 10^{-5} \mathrm{~mm}^{3} / \mathrm{Nm}\right)$ & 3.5 & 0.6 & \\
\hline \multirow{4}{*}{$\mathrm{CoCr}$} & \multirow{4}{*}{$\mathrm{HA}+12 \% \mathrm{Sr}$} & Surface roughness $(\mu \mathrm{m})$ & 1.2 & 4.6 & \multirow{4}{*}[58]{} \\
\hline & & Microhardness (HV) & 480 & 310 & \\
\hline & & Contact angle $\left(^{\circ}\right)$ & 93.81 & 56.12 & \\
\hline & & $\mathrm{I}_{\text {corr }}$ in Ringer's solution $\left(\mu \mathrm{A} \mathrm{cm}^{-2}\right)$ & 2.59 & 0.08 & \\
\hline \multirow{7}{*}{$\mathrm{CoCrNbMoZr}$} & \multirow{7}{*}{$\begin{array}{l}\text { Diamond-like } \\
\text { carbon-Ag }\end{array}$} & Contact angle $\left(^{\circ}\right)$ & 77 & 66 & \multirow{7}{*}{ [6] } \\
\hline & & $\begin{array}{l}\mathrm{I}_{\text {corr }} \text { in simulated body fluid (SBF) } \\
\qquad\left(\mu \mathrm{A} \mathrm{cm}^{-2}\right)\end{array}$ & 2.268 & 0.498 & \\
\hline & & $\mathrm{I}_{\text {corr }}$ in artificial saliva $\left(\mu \mathrm{A} \mathrm{cm}{ }^{-2}\right)$ & 1.127 & 0.390 & \\
\hline & & $\begin{array}{l}\text { Corrosion resistance due to the } \\
\text { surface oxide layer in SBF }(\Omega)\end{array}$ & 715.1 & 1185 & \\
\hline & & $\begin{array}{c}\text { Corrosion resistance due to the } \\
\text { surface oxide layer in artificial } \\
\text { saliva }(\Omega)\end{array}$ & 3055 & 4509 & \\
\hline & & $\begin{array}{l}\text { Growth inhibition index }(\mathrm{I} \%)-S . \\
\qquad \text { Aureus }\end{array}$ & $\begin{array}{l}\text { No antibacterial } \\
\text { activity }\end{array}$ & 61.75 & \\
\hline & & $\begin{array}{l}\text { Growth inhibition index }(\mathrm{I} \%)-P \text {. } \\
\text { Aeruginosa }\end{array}$ & $\begin{array}{l}\text { No antibacterial } \\
\text { activity }\end{array}$ & 56.4 & \\
\hline
\end{tabular}

This paper presents examples and the reasons why, during the last fifteen years, the industry and the biomedical field moved from conventional materials to micro- and nanolevel materials, as more technically, environmentally, or economical solutions. As can be observed in Table 1, in the last years, the selection of alloys and the development of their processing are also strongly influenced by the safe use and the behavior in the environment.

$\mathrm{CoCr}$ alloys were firstly introduced at the beginning of the last century, in the aerospace industry, for the remarkable corrosion resistance of these alloys is similar to stainless steel, which is based on the formation of a passivation thin layer of $\mathrm{Cr}_{2} \mathrm{O}_{3}$. The molybdenum addition produces finer grains, which induces higher strengths after the majority of processing. The chromium enhances corrosion resistance, as well as solid solution strengthening of the alloy. Being biocompatible, $\mathrm{CoCr}$ alloys have been used successfully as implant materials, both coated and uncoated. Despite the advantages, due to the toxicity of cobalt and the allergic reactions caused by $\mathrm{Ni}$ [59], the discussion to eliminate $\mathrm{CoCr}$ and $\mathrm{NiCr}$ from dentistry has arisen [60]. The prevalence of nickel allergy has been estimated years ago in around $28.5 \%$ of the general population, and cannot be considered anymore as having a low potential risk [61,62].

The cobalt chromium alloys are widely used in metal on metal, or metal on plastic bearing, due to their great wear and corrosion resistance $[57,63]$. This alloy is also used in coronary stents, due to its elasticity and plasticity [64]. As a part of the new EU Medical Devices Regulation (MDR) (2017/745), toxicological risks of the cobalt-chromium alloys used in dentistry have been proposed to be applied in 2021 [65], cataloging Co as carcino- 
genic, mutagenic, and detrimental for reproduction [66]. It is important to mention that the trend to eliminate the use of $\mathrm{CoCr}$ and $\mathrm{NiCr}$, due to toxicological risks evidenced in the $\mathrm{EU}$ regulations, has a relatively slow rate, and nowadays, more evaluations of their ion release are taking place [67]. Simultaneously with alternative strategies to reduce the risk of heavy metals for dental health, improving the quality of the $\mathrm{CoCr}$ alloys by changing their surface composition using coatings [68], new advanced technologies in obtaining CoCr for alloys have been tested $[69,70]$.

Regarding their use as biomaterials, besides the possible metal ion release, the difference in modulus between the alloy and the bone, and the resistance to wear are also problems that need to be addressed [63]. The problems related to wear are not limited to biomaterials, they are related to all mechanical parts of automobiles, aircraft engines, and various equipment [71].

Coatings can help in overcoming these issues, and further improved the alloys properties. A successful coating deposition was achieved on a $\mathrm{CoCr}$ alloy via laser-engineered net shaping, using premixed powders of CoCrMo and tricalcium phosphate, and CoCrMo, tricalcium phosphate, and $\mathrm{Al}_{2} \mathrm{O}_{3}$. The hardness was increased by $40.2 \%$ and $60.7 \%$, while the wear rate decreased by $82.3 \%$ and $71.6 \%$, respectively [63]. Other surface coatings aim at improving the biological interaction. A biofunctionalization of a CoCr alloy was performed with genetically modified elastin-like recombinamers, to selectively promote the endothelial cell adhesion and multiplication [64]. Another simple, effective method used to prepare a biomimetic coating on a $\mathrm{CoCr}$ substrate has proven to be the immersion of the pretreated substrate in PBS solution, obtaining a uniform layer of hydroxyapatite [72].

Although CoCr alloys may exhibit superior mechanical properties compared to stainless steels and $\mathrm{Ti}$ alloys, the ions released upon corrosion can induce hypersensitivity and induce inflammatory reactions. In an attempt to mitigate these issues, several coatings were developed over time. Hydroxyapatite-reinforced Sr powder was used to create a layer through plasma spray, obtaining increased mechanical properties and biocompatibility [58]. Other approaches considered creating a metallic coating composed of more biocompatible metals, $\mathrm{Nb}$ and $\mathrm{Ta}$. The coating was successful, obtaining improved corrosion resistance and increased hemocompatibility [56]. More-recent research describes the formation of a Ti nanolayer by thermal evaporation and posterior plasma nitriding processes, improving the tribological behavior of the uncoated alloy [73]. Also based on $\mathrm{Ti}$, a nanostructure $\mathrm{TiO}_{2}-\mathrm{Ag}$ coating was proposed to obtain an antimicrobial, bioactive surface [55].

Innovative strategies with both new advanced technologies and new coatings in obtaining new $\mathrm{CoCr}$ alloys have been introduced [6,70]. Regarding new compositions or alloys with new structures and properties, the trend is to involve more elements that are capable of inducing more functionality, even with the addition of small quantities. Frequently, such elements are rare elements, such as cerium, yttrium, or lanthanide, which are inducing remarkable mechanical properties and stability at elevated temperatures [74-76].

In the last decade, the strategy to design high-entropy alloys (HEAs) for structural service in the transportation and energy industries has significantly enlarged [77]. HEAs were designed for low $\left(\leq 150{ }^{\circ} \mathrm{C}\right)$, medium $\left(\leq 450{ }^{\circ} \mathrm{C}\right)$, and high $\left(\geq 1100{ }^{\circ} \mathrm{C}\right)$ service temperatures. The intermetallic phases were proposed as consistent with HEA definitions, and the strategy developed includes both single-phase, solid solution HEAs and HEAs with intentional addition of a second phase for particulate hardening [78].

The thermodynamic evaluation was helping to systematically screen and evaluate a large number of HEAs, by integrating high-throughput computations and experiments. The HEAs had attracted attention, due to their high strength/hardness, high wear resistance, high fracture toughness, excellent low- and high-temperature performance and structural stability, good corrosion, and oxidation resistance $[79,80]$.

The initial approach of HEA manufacturing was to increase the element number and, simultaneously, the mixing entropy of the material, to establish a stable solid solution for alloy formation. It is an idea for multi-principal element alloys (MPEAs) or complex alloys (CCAs) to provide better performance through composition adjustment and by controlling 
the phase composition, including transitions from a single-phase solid solution towards a variety of complex phase compositions [81]. In such a way, a vast number of HEAs were divided into two main categories, after analyzing their deformation mechanisms [82]. The first category is based on the crystallographic structure of the phase, and it includes FCC-based, BCC-based, HCP-based, amorphous, and intermetallic HEAs. The second category, based on the type of phase, includes single-phase, dual-phase, eutectic, and multi-phase HEAs [83].

The most used techniques to prepare HEAs in bulk are ingot metallurgy, powder metallurgy, and selective laser melting [84], while laser cladding and magnetron sputtering methods are commonly used to prepare HEA coatings $[49,85]$. The selective laser melting technology (SLM) was investigated with $\mathrm{Ar}$ and $\mathrm{N}_{2}$ as protective gases, on the alloy $\mathrm{CoCr}_{2.5} \mathrm{FeNi}_{2} \mathrm{TiW}_{0.5}$. It was observed that the use of Ar led to the formation of a singlephase solid solution, while the use of $\mathrm{N}_{2}$ led to the formation of a second phase (TiN). Although some studies suggest that a single-phase solid solution is preferred, the average yield strength, ultimate tensile strength, and average elongation showed higher values in the case of $\mathrm{N}_{2}$ [86].

One of the downsides of preparing HEA is the cost associated with the production of such an alloy, due to the large percentage of rare metals. Methods for improving the problems associated with this are already starting to emerge. Therefore, to benefit from the properties of these materials, but also consider the sustainability principles, HEA coatings can be created on simpler substrates. To investigate this, a $\mathrm{CoCr}_{2} \mathrm{FeNiMo}_{\mathbf{x}}$ coating was created through the laser cladding method, on a carbon steel substrate. It was observed that the coating provided improved mechanical properties and increased corrosion resistance [34]. A similar coating, also created by laser cladding, consisting of $\mathrm{CoCr}_{2.5} \mathrm{FeNi}_{2} \mathrm{Tix}$, was created on a stainless steel substrate, obtaining increased corrosion resistance and improved hardness [35].

The zirconium alloys, namely, zircaloys, are widely researched as accident-tolerant fuels, especially after the Fukushima accident. Their mechanical properties, as well as their corrosion resistance and neutron irradiation resistance, make them a good fuel cladding material. One of the biggest challenges is that, in contact with high-temperature, large levels of hydrogen are released. Several coatings have been proposed to help with this issue, $\mathrm{FeCrAl}, \mathrm{CrAlN}, \mathrm{CrAlSiN}, \mathrm{SiC}, \mathrm{CN}, \mathrm{Cr}$ [87-92]. Moreover, zirconium and zirconium alloys are used as implant materials, having great biocompatibility [93-95].

Titanium and titanium alloys are also intensively used in a large number of applications, due to their outstanding corrosion resistance, great mechanical properties, and good biocompatibility $[54,96]$. A problem with these alloys as biomaterials is that they may be a cause of thrombosis when they come into contact with blood, as in the case of coronary stents, and anticoagulation medication is usually prescribed to prevent this from happening. Coatings that encapsulate drugs, such as aspirin, have been proposed to further improve the biocompatibility [97]. Other coatings aim at improving the biocompatibility by obtaining bacteriostatic $[98,99]$ and bactericidal [100] properties. In other applications, such as the aerospace industry, the mechanical properties of titanium alloys need further improvement, and multiple hard coatings were developed as a solution [100].

Furthermore, creating different oxide nanocomposites from oxides such as, $\mathrm{ZrO}_{2}$, $\mathrm{ZnO}_{2}$, and $\mathrm{TiO}_{2}$ is also of great interest nowadays, due to their potential multifunctional properties, such as antibacterial, antireflecting, self-cleaning, etc. [101]. Additionally, for the synthesis of $\mathrm{TiO}_{2}$ nanoparticles, a large number of green methods have already been proposed, based on extracts from plants, fungi, and even bacteria [102].

\section{New Challenges in Coatings on Biodegradable Mg Alloys}

The biodegradable $\mathrm{Mg}$ alloys show great potential as biomaterials, due to their density and elastic modulus, which are very close to those of the human bone. However, their high degradation rate may not be suitable in all cases [103-106]. They are also investigated for other fields, such as electronics, aerospace, automotive, etc. $[107,108]$. It is clear that 
not all $\mathrm{Mg}$ alloys behave in the same way, and that choosing the alloying elements is the first step in developing a successful material. Different elements, and their influence on the microstructure and the corrosion resistance, were presented by Fattah-alhosseini and Chaharmahali in a review study [109].

Magnesium alloys react easily in the physiological environment, considering a neutral $\mathrm{pH}$, the following reaction takes place:

$$
\mathrm{Mg}+2 \mathrm{H}_{2} \mathrm{O} \rightarrow \mathrm{Mg}^{2+}+2 \mathrm{OH}^{-}+\mathrm{H}_{2} \uparrow
$$

Due to the hydrogen gas resulted in the reaction, which is only tolerated in a very low dose $\left(0.01 \mathrm{~mL} / \mathrm{cm}^{2} /\right.$ day $)$, a gas pocket may form, leading to implant failure. Moreover, both the hydrogen and the hydroxyl anion can disrupt cellular functions. Additionally, the local alkalization leads to the formation and precipitation of hydroxides on the alloy surface, which can react with the chloride anions, causing pitting corrosion [110-112].

Creating surface coatings may help in overcoming this limitation. Moreover, functional coatings can further improve the biocompatibility of such alloys [113-117]. Several novels, multifunctional coatings are presented in Table 2, and some of these, along with others, are discussed in more detail below.

Table 2. Multifunctional coatings on Mg alloys.

\begin{tabular}{|c|c|c|c|c|c|}
\hline Substrate & Coating & $\begin{array}{l}\text { Coating's } \\
\text { Characteristic }\end{array}$ & Method Used & Results & Ref. \\
\hline MgAlZn (AZ31) & $\begin{array}{c}\text { Nanocontainers of } \\
\text { 2-mercaptobenzothiazole } \\
\text { loaded with mesoporous } \\
\text { silica nanoparticles and } \\
\text { layered double hydroxide } \\
\text { nanosheets shell }\end{array}$ & $\begin{array}{l}\text { Nanocontainers with } \\
\text { uniform spherical shape } \\
\text { with an approximate } \\
\text { diameter of } 90 \mathrm{~nm} \text { after } \\
\text { loading and encapsulation }\end{array}$ & Dip coating & $\begin{array}{l}\text {-highly improved } \\
\text { corrosion resistance }\end{array}$ & [118] \\
\hline $\begin{array}{l}\mathrm{MgAlZn} \\
(\mathrm{AZ} 31)\end{array}$ & $\begin{array}{c}\text { Micro-arc } \\
\text { oxidation/ciprofloxacin- } \\
\text { polymethyltrimethoxysilane }\end{array}$ & $\begin{array}{l}\text { Bird-like structure, } \\
\text { approximate thickness of } \\
35 \mu \mathrm{m}\end{array}$ & $\begin{array}{l}\text { Micro-arc oxidation } \\
\text { and dipping }\end{array}$ & $\begin{array}{l}\text {-increased corrosion } \\
\text { resistance } \\
\text {-long-term drug release } \\
\text {-efficient inhibition on } \\
\text { S. aureus and E. Coli }\end{array}$ & [119] \\
\hline $\begin{array}{l}\mathrm{MgAlZn} \\
(\mathrm{AZ} 31)\end{array}$ & $\begin{array}{c}\mathrm{MgO} \text { and } \\
\text { polytetrafluoroethylene } \\
\text { nanoparticles }\end{array}$ & $\begin{array}{l}\text { Polymer-like, porous } \\
\text { multilayer with rough } \\
\text { surface texture }\end{array}$ & $\begin{array}{l}\text { Plasma-induced } \\
\text { thermal-filed assisted } \\
\text { crosslink deposition }\end{array}$ & $\begin{array}{l}\text {-superhydrophobic } \\
\text {-improved mechanical } \\
\text { properties } \\
\text {-high-temperature } \\
\text { resistance } \\
\text {-self-cleaning } \\
\text {-low friction coefficient }\end{array}$ & [116] \\
\hline $\begin{array}{l}\mathrm{MgAlZn} \\
(\mathrm{AZ} 31)\end{array}$ & $\begin{array}{c}\text { 2-methylene-1,3- } \\
\text { dioxepane,vinyl acetate, } \\
\text { 7-(2-methacryloyloxyethoxy)- } \\
\text { 4-methylcoumarin, and } \\
\text { dopamine methacrylamide }\end{array}$ & $\begin{array}{l}\text { Biodegradable copolymer } \\
\text { coating }\end{array}$ & $\begin{array}{c}\text { Electrophoretic } \\
\text { deposition and UV } \\
\text { irradiation treatment }\end{array}$ & $\begin{array}{l}\text {-increased corrosion } \\
\text { resistance } \\
\text {-good cytocompatibility }\end{array}$ & [120] \\
\hline MgZnYNd & $\begin{array}{c}\text { hyaluronic } \\
\text { acid/polyethyleneimine } \\
\text { nanoparticles after } \\
\text { fluorination/poly-dopamine } \\
\text { treatment }\end{array}$ & $\begin{array}{l}\text { Hydrophilic surface with } \\
\text { different roughness } \\
\text { depending on the size of } \\
\text { the nanoparticles }\end{array}$ & Dip coating & $\begin{array}{l}\text {-improved corrosion } \\
\text { resistance } \\
\text {-better biocompatibility }\end{array}$ & [121] \\
\hline $\begin{array}{l}\text { MgYNdZr } \\
\text { (WE43) }\end{array}$ & $\begin{array}{l}\text { poly(etherimide) and } \\
\text { sirolimus loaded } \\
\text { poly(lactic-co-glycolic acid) }\end{array}$ & $\begin{array}{l}\text { Polymer asymmetric } \\
\text { coating, consisting of an } \\
\text { inner single layer and an } \\
\text { outside/side sirolimus } \\
\text { loaded double layer }\end{array}$ & $\begin{array}{l}\text { Sequential spray } \\
\text { coating }\end{array}$ & $\begin{array}{l}\text {-great substrate } \\
\text { adhesion } \\
\text {-improved } \\
\text { cytocompatibility and } \\
\text { corrosion resistance } \\
\text {-slow release rate of } \\
\text { sirolimus }\end{array}$ & [122] \\
\hline
\end{tabular}


Table 2. Cont

\begin{tabular}{|c|c|c|c|c|c|}
\hline Substrate & Coating & $\begin{array}{l}\text { Coating's } \\
\text { Characteristic }\end{array}$ & Method Used & Results & Ref. \\
\hline $\mathrm{MgZnMn}$ & nano-hydroxyapatite (nHA) & $\begin{array}{l}\text { Cubical nanoparticles with } \\
\text { interconnected surface } \\
\text { porosities of } 5-10 \mu \mathrm{m} \text {. } \\
\text { Coating thickness between } \\
12 \text { and } 22 \mu \mathrm{m} \text { depending on } \\
\text { the nHA concentration }\end{array}$ & $\begin{array}{l}\text { Electric discharge } \\
\text { machining }\end{array}$ & $\begin{array}{l}\text {-very reduced } \\
\text { degradation rate } \\
\text {-increased } \\
\text { microhardness } \\
\text {-improved } \\
\text { cytocompatibility }\end{array}$ & [113] \\
\hline $\mathrm{MgCaZn}$ & $\begin{array}{c}\mathrm{Ta}_{2} \mathrm{O}_{5} \text { and poly } \\
\text { (E-caprolactone)/MgO-Ag }\end{array}$ & $\begin{array}{l}\text { Dense film of } \mathrm{Ta}_{2} \mathrm{O}_{5} \text {, with } \\
\text { no cracks or pores covered } \\
\text { with nanofibers } \\
\text { (200-360 nm diameter) with } \\
\text { porous structure }\end{array}$ & $\begin{array}{l}\text { Magnetron } \\
\text { sputtering and } \\
\text { electrospinning } \\
\text { coating }\end{array}$ & $\begin{array}{l}\text {-improved corrosion } \\
\text { resistance } \\
\text {-antibacterial activity }\end{array}$ & [123] \\
\hline $\mathrm{MgZnCa}$ & Silk fibroin/sodium alginate & $\begin{array}{l}\text { Uniform coating, without } \\
\text { cracks, with an average } \\
\text { thickness of } 5 \mu \mathrm{m}\end{array}$ & $\begin{array}{l}\text { Micro-drop } \\
\text { deposition }\end{array}$ & $\begin{array}{l}\text {-improved mechanical } \\
\text { properties and } \\
\text { corrosion resistance }\end{array}$ & [104] \\
\hline MgZnYNd & $\begin{array}{l}\text { poly-dopamine/hyaluronic } \\
\text { acid (HA) }\end{array}$ & $\begin{array}{l}\text { Surface with particles of } \\
\text { several micrometers and } \\
\text { various roughness } \\
\text { depending on the } \\
\text { molecular weight of the HA } \\
\text { used }\end{array}$ & Dip coating & $\begin{array}{l}\text {-improved corrosion } \\
\text { resistance } \\
\text {-pro-endothelialization } \\
\text { ability }\end{array}$ & [106] \\
\hline
\end{tabular}

In the case of biomaterials, most coatings focus on calcium phosphate, as it is the main component of the bone tissue and has excellent biocompatibility. Multiple physical and chemical methods have been developed with time, which can create such coatings. One of these methods, which can be performed at room temperature and does not require high cost, is the electrodeposition method [124]. Plasma electrolytic oxidation (PEO), also known as micro-arc oxidation (MAO), is another promising technique that is capable of creating coatings based on the species that originate from the substrate, and the species from the electrolyte used [125]. The method was successfully used on a $\mathrm{Mg}-5 \mathrm{Zn}-0.4 \mathrm{Ca}$ alloy in a phosphate solution, creating a porous, three-layer coating. The electrochemical data showed a decrease in the corrosion current and an increase in the corrosion resistance, compared to the $\mathrm{Mg}$ substrate [126].

Three different coatings were created on a $\mathrm{Mg}$ alloy $(\mathrm{Mg}-2 \mathrm{Zn}-1 \mathrm{Gd}-0.5 \mathrm{Zr})$, to decrease the degradation rate and improve the resistance to wear. One coating was achieved through $\mathrm{MAO}$, using $\mathrm{KF},\left(\mathrm{NaPO}_{3}\right)_{6}$ and $\mathrm{Ca}(\mathrm{OH})_{2}$, while the other two coatings were performed through immersion of the sample. For the coating named Ca-P, the samples were immersed in $\mathrm{KF}$ for $24 \mathrm{~h}$, after which they were placed in a solution that contained $\mathrm{NaNO}_{3}, \mathrm{Ca}\left(\mathrm{H}_{2} \mathrm{PO}_{4}\right)_{2}$, and $\mathrm{H}_{2} \mathrm{O}_{2}$ for another $24 \mathrm{~h}$, and for the coating named $\mathrm{Sr}-\mathrm{P}$, the samples were immersed in a solution containing $\mathrm{Sr}\left(\mathrm{NO}_{3}\right)_{2}$ and $\mathrm{NH}_{4} \mathrm{H}_{2} \mathrm{PO}_{4}$ at $80{ }^{\circ} \mathrm{C}$ for $12 \mathrm{~min}$. It was observed that through $\mathrm{MAO}$ and $\mathrm{Sr}-\mathrm{P}$ coatings, the degradation resistance of the alloy was improved, while the Ca-P coating increased the wear resistance [103].

In another study on a Mg-Ca alloy, the coating formed through MAO was further improved by creating another coating on top of poly (lactic acid) (PLA), through a simple dip-coating process. This second layer has effectively sealed the porosities of the first layer, improving the corrosion resistance even more [127].

Graphene and graphene oxide were also used with PEO to create a thicker coating layer that improves the corrosion resistance and the resistance to wear [109].

While some coatings may help in solving the problems related to this type of alloy, researchers must avoid introducing possible additional problems, as in the case of nondegradable coatings. With this idea in mind, several degradable coatings have been studied, poly-L-lactide (PLLA), poly(3-hydroxybutyrate) (PHB), poly(3-hydroxybutyrateco-3-hydroxyvalerate) (PHBV), and poly(lactic-co-glycolic) acid (PLGA). These coatings were prepared through spin-coating, giving uniform, non-porous coatings. From this, PLLA, PHB, and PHBV had successfully suppressed the corrosion of the substrate, due to the lower water permeability, and also improved cell proliferation [110]. 
Another approach that showed positive results and must be considered is related to the treatment of the substrate before coating. In a research conducted by Li et al., it was shown that by changing the microstructure through equal channel angular pressing (ECAP) before MAO coating, the degradation rate can be further improved and so can the mechanical properties of the alloy. By refining the grain size, it was possible to obtain a denser coating, compared to the alloy as-cast; therefore, the corrosion resistance was improved [128].

Aiming at saving time and improving the costs, one of the techniques used for cutting and shaping biomaterials (electric discharge machining-EDM) was also used to create a coating of nano-hydroxyapatite on a $\mathrm{Mg}-\mathrm{Zn}-\mathrm{Mn}$ alloy. The coating helped in reducing the degradation rate by $90.85 \%$, while improving cell attachment and proliferation [113,129].

More recently, researchers are starting to create a path for multifunctional coatings that could extend the use of this type of alloy in challenging environments $[118,119,130]$. One such method was developed to create a multilayer with both organic and inorganic components, through plasma-induced thermal-field-assisted crosslinking deposition (PTCD). The method is an eco-friendly method, allowing hierarchical textures to be created, in which the inorganic layer and the organic layer grow simultaneously, in one step [116].

Another issue with biodegradable $\mathrm{Mg}$ alloys, besides their fast degradation rate, is the poor antibacterial performance. The use of nanoparticles, nanofibers, or multilayer coatings to inhibit bacterial infections or to provide a suitable substrate for drug-loading is gaining more and more attention. Following the idea of inducing antibacterial properties, a type of surface coating was proposed, using silver-doped hydroxyapatite nano-powder (Ag-HA) by micro-arc oxidation. The coating clearly provided antibacterial properties, but decreased the corrosion resistance [131].

Research on a Mg-Ca-Zn alloy that was aiming at tackling both these issues, while considering the sustainability principles, has proposed a surface coating with a layer of tantalum oxide $\left(\mathrm{Ta}_{2} \mathrm{O}_{5}\right)$, through physical vapor deposition (PVD), to reduce the degradation rate, followed by a layer of poly( $\varepsilon$-caprolactone)/magnesium oxide-silver (PCL/MgO-Ag) through electrospinning, to induce antibacterial properties [123].

\section{Nanofabrication Aspects of Green Procedures in Enhancing Coatings Multifunctionality (Green Corrosion Inhibitors, Biomimetic Coatings, Bioinspired Coating Based on Superhydrophilic and Superhydrophobic Coatings, Smart Additives)}

In the initial time of their applications, nanotechnology and nanostructures were regarded as having only positive effects in many fields, but after the initial period, when more knowledge had been accumulated, especially regarding the impact on health, the merits and demerits were better understood [132,133]. In the coatings world, the nanostructures benefits were exploited successfully, enhancing performance and functionality in many domains, introducing more stability and corrosion resistance in various aggressive environments, including bioliquids. A better cell response, as well as more adhesion and better mechanical properties [134-136] were obtained via more green coating fabrication methods. Some multifunctional coatings that are discussed in more detail below are presented in Figure 2.

Various procedures are practically used to control metals corrosion, and coatings are the most widely performed for this purpose [137-139]. Generally, coatings to retard corrosion act by one or a combination of the following mechanisms: (1) cathodic protection, with a more electropositive material serving as sacrificial anode [140]; (2) anodic passivation by the formation of a passive layer that acts as a barrier against corrosion [141]; (3) electrolytic inhibition, which impedes the corrosion, blocking the transport of ions between the anode and cathode using a diffusion barrier [142]; and (4) active corrosion inhibition, which bind ligands to the metal surface, stopping corrosion development [139]. Active corrosion inhibition based on barrier building involves the coating failure and the incorporation of components selectively released upon coating damage, into the newly formed protective barrier on the metal surface $[138,143]$. 

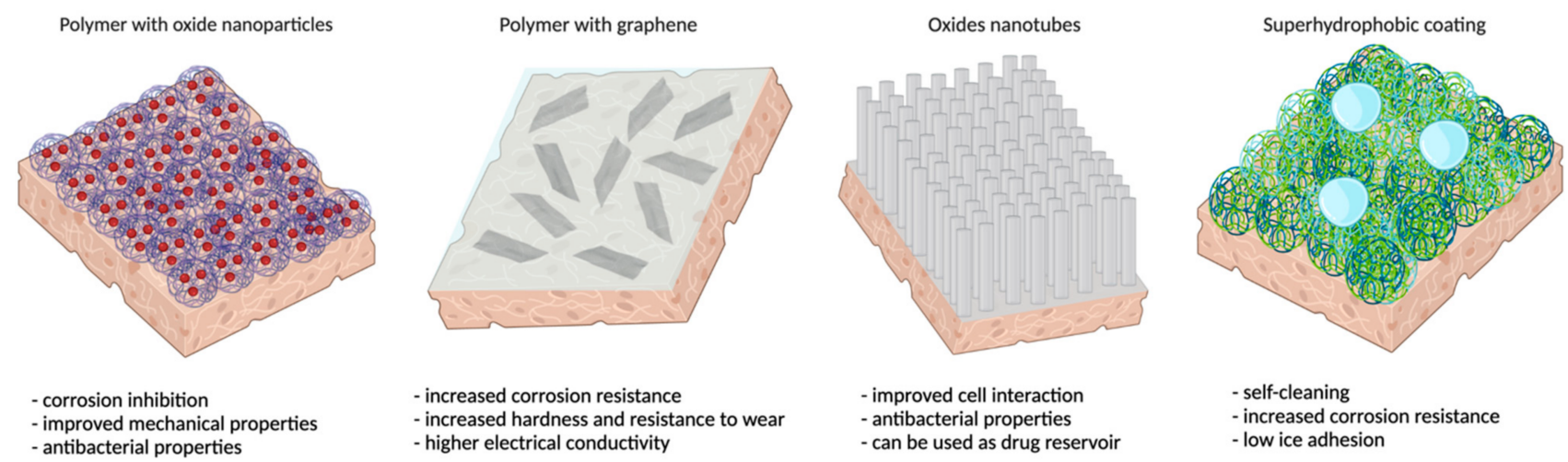

Figure 2. Schematic representation of some multifunctional coatings on metallic alloys and their properties/applications.

The polymers used for coating [144] have weak resistance to the penetration of corrosive solution at the metal/coating interface, and introducing nanoparticles in polymer coating is improving the protection of the surface [145]. Depending on the nanoparticle type and dimensions, the new hybrid coating could induce other properties, such as antibacterial inhibition, wear resistance, etc. We mention the recent investigation related to the incorporation of $\mathrm{ZnO}$ nanoparticles into nanosilica-containing epoxy formulations, leading to not only better corrosion resistance, but enhanced mechanical properties as well [146]. Nanocomposites in which the nanoparticles of one phase are dispersed within a continuous polymeric matrix phase represent a topical design approach to multifunctional coatings, resolving problems such as dispersion and compatibility [140].

The incorporation of metallic, porous metal oxide, graphene, and carbon nanotubes within polymeric matrices are explored and explained as active corrosion inhibition $[147,148]$. Such an active corrosion retard mechanism is based on the electroactive properties of metals, graphene, carbon nanotubes, or on their ability to serve as reservoirs for active corrosion inhibitors such as porous silicon oxide, layered double hydroxides, and halloysite $[149,150]$. Both ways of action provide multifunctional opportunities for novel coatings [140], developing a systematic design approach for corrosion inhibition when other properties are induced as well.

Smart coatings based on the polymer matrix doped with carbon nanomaterials, such as carbon nanotubes or graphene, enhance their performance, increasing their barrier properties, corrosion resistance, hardness, and wear strength [151-155]. This is a new generation of protective organic coatings, capable to respond intelligently to damage or external stimuli. Carbon nanostructures induce new functionalities to coatings [156], related to the higher electrical conductivity [142] of nanocomposites, due to the percolation network formation. Having electrical resistance, such coatings can be used as sensors and gauges, and act as self-heaters. When an electrical voltage is applied, it can be used in defogging and deicing.

The design of graphene nanocomposite coatings for aluminum alloy protection is also an important aspect of sustainable and green procedure for aircraft industry development. Aluminum itself, as structural aircraft material, has an excellent passive layer, but the need to stabilize high-strength alloys involves the addition of other components, leading to a complex microstructure with various intermetallic inclusions that render the resulting material more vulnerable to local corrosion. Chromium-based conversion coating is a remarkable protection of aluminum, but it is well known that hexavalent chromium effluents released at various points in production, as a byproduct, have a highly toxic and carcinogenic effect [142]. The ecological toxicity and human health impact of hexavalent chrome have led to the strict regulation of its use in products [140,157], and no chromate pretreatment being imposed [158].

With the increasing use of aluminum alloys for vehicular applications, the development of sustainable chrome-free coatings has emerged as imperative. Zinc and trivalent chrome are used frequently to protect steel substrates, but are ineffective in providing 
sacrificial cathodic protection to aluminum alloys, due to the value of aluminum redox potential. Magnesium-based nanocomposite coatings have been developed, but, due to the high reactivity of $\mathrm{Mg}$ particles, the safe preparation of a surface-passivated $\mathrm{Mg}$ surface is difficult, especially in some environments [159]. The graphene nanocomposite coating with sub-30 $\mu \mathrm{m}$ thickness is a successful alternative when it is dispersed in a matrix such as a polyetherimide matrix, showing very good corrosion inhibition of Al 7075 substrates, even when exposed to saline environments for a long time [160].

Biomimetic coatings are another type of coatings, inspired from nature, as nature has already solved many complex problems through natural selection. Therefore, these coatings have been investigated in different areas, such as solutions for marine biofouling [161], building construction materials [162], and medicine [163].

The synthesis of biomimetic coatings is showing very promising results in medicine, creating materials with improved biocompatibility [164-166], while, in other areas, the morphology of these bioinspired coatings generates versatile properties, such as a hair-like composite coating, consisting of $\mathrm{Fe}_{3} \mathrm{O}_{4}$ particles, resin, and perfluorodecyltriethoxysilane, which has water-collecting and superamphiphobic properties [167], or a flower-like coating, composed of $\mathrm{CeO}_{2}$ and polydopamine, creating a superhydrophobic surface that can be used to prevent hydrate plugging [168].

An important characteristic of modern coatings, which can define future applications, is the value of contact angle. A coating with a contact angle value greater than $150^{\circ}$ in water is a superhydrophobic surface, and presents not only deicing ability, but also stimulichromism, antibacterial activity, flame retardant, and lubricating properties. Coatings with contact angle values less than $90^{\circ}$ are hydrophilic, and when the values are under $10^{\circ}$, the surface is superhydrophilic [169-171]. A large number of coating components can increase or decrease the contact angle, leading to a biomimetic structure that is able to induce special properties and multifunctionality. An example of a contact angle decrease leading to better performance is anodic oxidation on the surface of the ZrTi substrate. The anodizing process of the ZrTi substrate is a simple and low-cost method, and depending on the chosen anodizing parameters (duration of anodizing, electrolyte, etc.), the structure and the morphology vary, leading to different types of nanostructures, such as pores, tubes, or channels [172-175]. After annealing, the nanopores and nanotubes oxides $\left(\mathrm{Zr}_{3} \mathrm{O}\right.$, $\left.\mathrm{ZrO}_{2}\right)$, along with TiZr mixed oxides $\left.\left(\mathrm{Ti}_{2} \mathrm{ZrO}_{6}, \mathrm{Ti}_{2} \mathrm{ZrO}, \mathrm{ZrTiO}\right)_{4}\right)$, have contact angle values between $2^{\circ}$ and $6^{\circ}$, and present an antibacterial effect. An interesting correlation between contact angles, roughness values, their stability in bioliquids, and biological aspects was obtained for investigations performed on the hybrid complex coating on the same alloy substrate, covered with a biomimetic composition of hydroxyapatite (HA) and chitosan (CS) in various ratios. Compared with the noncoated alloy, and depending on the chitosan content, this bioinspired coating presents better properties; the most hydrophilic one, with the ratio HA:CS $=1: 2$, has the lowest reactive oxygen species (ROS) level and the best organized actin cytoskeleton, which promotes the most remarkable cell proliferation rate $[176,177]$.

Another superhydrophilic surface with many more multifunctional applications, such as self-cleaning, oil/water separation, antifogging, etc., was elaborated in a one-step coating method [178] that is suitable for a variety of substrates, both inorganic and organic, using the coordination complexes of natural phytic acid (PA) and Fe(III) ions. The final coatings are very thin and transparent, elaborated in a fast process that is cost-effective and environmentally friendly. The high density of phosphonic acid groups was proposed to be responsible for the superhydrophilicity in such a procedure [178]. A plant-inspired, layer-by-layer, self-assembly, superhydrophobic modification of various highly hydrophilic polymer materials, based on a molecular building block of the PA-Fe(III) complex to anchor the substrate and the hydrophobic thiol groups (HT), was proposed initially, to separate the oil-water mixture and oil spill clean-up [179]. It is a green modification method that can be applied to a variety of substrates. 
According to the Cassie-Baxter model [180], the hydrophobic behavior of the material surface is a synergic effect of the chemical properties and the roughness of the material surface. Although silicon/fluorine materials are known as very low surface energy materials, with remarkable properties, such as weather and corrosion resistance, and refractory and oxidation stability [181], the high price of silicon/fluorine-modified coatings, and their difficult elaboration process, limits their applications. A more economical method to fabricate a formulation based on fluorine resins and $\mathrm{SiO}_{2}$ nanoparticles yielded performance comparable to other commercially available systems. This was applied for the conservation of the monuments allowing graffiti removal, and decreasing damages [182], with fewer costs and environmental impacts. Other methods based on the increase in contact angles were developed, introducing various polymeric sponges with superhydrophobic properties [183].

Smart additives, such as self-sealing and self-healing, based on graphene penetrated the plastic industry, being used in greenhouse, food packaging, and self-curing concrete applications. Multifunctional graphene-based nano-additives and high-performance polymer nanocomposites have enhanced mechanical, thermal, flame retardancy, and smokesuppressive properties [17], being another example of nano-aspects for sustainable methods, increasing the life of materials.

To summarize the important achievements in the field of nanocoatings, it is important to have a look at the development of nanocontainer-based self-healing coatings that are able to release anticorrosion inhibitor agents or other active components. The concept of such coatings combines the classic passive component of the coating matrix (layer) with an active agent that is responsive for both internal and external events in different environments [184].

In the last years, the role of green attributes in production processes of sustainable coatings was established, and their impact on operational, commercial, and economic benefits was understood, contributing to a better coatings selection [185].

\section{Conclusions}

In the last decades, we have become significantly more aware of the impact that we have on the environment, and have gathered a better understanding of the processes happening at the sub-micrometer level. Through a combination of this knowledge, we observe a rapid increase in the research areas towards designing materials at the nanometric scale, while evaluating the sustainability of the processes involved. Researchers are continuously evaluating methods and materials to find the right combinations between materials properties, and safe, economical, and environmentally friendly methods.

The coatings developed nowadays are more complex, regarding both composition and design. Regardless of the alloy used as the substrate, there is increased research on polymeric coatings that include nanoparticles or active pharmaceutical substances, and sometimes even both. Other coatings, consisting of metallic oxide nanostructures and graphene-based nanostructures, are also of great interest, due to the multifunctional nature of these coatings. High-entropy alloy coatings must also be mentioned, as they represent a relatively new area that we are just beginning to explore, but are already showing great results.

Although things are evolving at a very fast pace, we observe that research is keeping up and finds sustainable solutions. The difficult part may be implementing these solutions in the industry sector, and the real challenge is to make these changes fast enough, so that the environmental damage will not become irreversible. We can say that greener coatings in all kinds of fields, including biomedical, electronic, automotive, and construction applications, are the right response to the current challenges.

Author Contributions: Conceptualization, I.D.; methodology, I.D. and D.I.; investigation, R.N., D.I. and I.D.; writing-original draft preparation, R.N., D.I. and I.D.; writing-review and editing, I.D. and D.I.; visualization, R.N.; supervision, I.D. All authors have read and agreed to the published version of the manuscript. 
Funding: This research received no external funding.

Institutional Review Board Statement: Not applicable.

Informed Consent Statement: Not applicable.

Data Availability Statement: Not available.

Conflicts of Interest: The authors declare no conflict of interest.

\section{References}

1. Wen, C.E.; Xu, W.; Hu, W.Y.; Hodgson, P.D. Hydroxyapatite/titania sol-gel coatings on titanium-zirconium alloy for biomedical applications. Acta Biomater. 2007, 3, 403-410. [CrossRef]

2. Calderon Moreno, J.M.; Osiceanu, P.; Vasilescu, C.; Anastasescu, M.; Drob, S.I.; Popa, M. Obtaining, structural and corrosion characterization of anodized nanolayers on Ti-20Zr alloy surface. Surf. Coat. Technol. 2013, 235, 792-802. [CrossRef]

3. Ionita, D.; Grecu, M.; Ungureanu, C.; Demetrescu, I. Antimicrobial activity of the surface coatings on TiAlZr implant biomaterial. J. Biosci. Bioeng. 2011, 112, 630-634. [CrossRef]

4. Wang, Y.; Yu, H.; Chen, C.; Zhao, Z. Review of the biocompatibility of micro-arc oxidation coated titanium alloys. Mater. Des. 2015, 85, 640-652. [CrossRef]

5. Wang, D.; Bierwagen, G.P. Sol-gel coatings on metals for corrosion protection. Prog. Org. Coat. 2009, 64, 327-338. [CrossRef]

6. Ionita, D.; Golgovici, F.; Mazare, A.; Badulescu, M.; Demetrescu, I.; Pandelea-Dobrovicescu, G.R. Corrosion and antibacterial characterization of Ag-DLC coatingon a new CoCrNbMoZr dental alloy. Mater. Corros. 2018, 69, 1403-1411. [CrossRef]

7. Perry, K.K. The Dynamics of Industrial Development in a Resource-Rich Developing Society: A Political Economy Analysis. J. Dev. Soc. 2018, 34, 1-33. [CrossRef]

8. VerLoren van Themaat, W.; Reuder, B. Treaty on European Union (TEU). In European Competition Law; Edward Elgar Publishing: Cheltenham, UK, 2018; pp. 3-4.

9. Rai, P.; Mehrotra, S.; Priya, S.; Gnansounou, E.; Sharma, S.K. Recent advances in the sustainable design and applications of biodegradable polymers. Bioresour. Technol. 2021, 325, 124739. [CrossRef]

10. Florez, L.; Castro-Lacouture, D. Optimization model for sustainable materials selection using objective and subjective factors. Mater. Des. 2013, 46, 310-321. [CrossRef]

11. Kumar, P.; Kumar, A.; Fernandes, T.; Ayoko, G.A. Nanomaterials and the Environment. J. Nanomater. 2014, 2014, 1-4. [CrossRef]

12. Roghanian, N.; Banthia, N. Development of a sustainable coating and repair material to prevent bio-corrosion in concrete sewer and waste-water pipes. Cem. Concr. Compos. 2019, 100, 99-107. [CrossRef]

13. Li, Y.; Li, L.; Sun, J. Bioinspired self-healing superhydrophobic coatings. Angew. Chem. Int. Ed. 2010, 49, 6129-6133. [CrossRef]

14. Pal, K.; Kyzas, G.Z.; Kralj, S.; Gomes de Souza, F. Sunlight sterilized, recyclable and super hydrophobic anti-COVID laser-induced graphene mask formulation for indelible usability. J. Mol. Struct. 2021, 1233, 130100. [CrossRef]

15. Rani, B.E.A.; Basu, B.B.J. Green inhibitors for corrosion protection of metals and alloys: An overview. Int. J. Corros. 2012, 2012, 1-15. [CrossRef]

16. Obot, I.B.; Umoren, S.A.; Ankah, N.K. Pyrazine derivatives as green oil field corrosion inhibitors for steel. J. Mol. Liq. 2019, 277, 749-761. [CrossRef]

17. Huang, G.; Chen, W.; Wu, T.; Guo, H.; Fu, C.; Xue, Y.; Wang, K.; Song, P. Multifunctional graphene-based nano-additives toward high-performance polymer nanocomposites with enhanced mechanical, thermal, flame retardancy and smoke suppressive properties. Chem. Eng. J. 2021, 410, 127590. [CrossRef]

18. Rawat, S.S.; Harsha, A.P.; Chouhan, A.; Khatri, O.P. Effect of Graphene-Based Nanoadditives on the Tribological and Rheological Performance of Paraffin Grease. J. Mater. Eng. Perform. 2020, 29, 2235-2247. [CrossRef]

19. Pourhashem, G. Coating a Sustainable Future. Coatings 2020, 10, 713. [CrossRef]

20. Tyagi, P.; Salem, K.S.; Hubbe, M.A.; Pal, L. Advances in barrier coatings and film technologies for achieving sustainable packaging of food products-A review. Trends Food Sci. Technol. 2021, 115, 461-485. [CrossRef]

21. Stoian, A.B.; Demetrescu, I.; Ionita, D. Nanotubes and nano pores with chitosan construct on TiZr serving as drug reservoir. Colloids Surf. B Biointerfaces 2020, 185, 110535. [CrossRef]

22. Jariya, S.A.I.; Ravichandran, K.; Narayanan, T.S.N.S. Development of novel multi-functional composite coatings on titanium: Evaluation of structural characteristics, bioactivity and corrosion behaviour. J. Alloys Compd. 2021, 855, 157290. [CrossRef]

23. Zheng, Y.; Zhang, C.; Wang, L.; Long, X.; Zhang, J.; Zuo, Y.; Jiao, F. Tannic acid-based complex coating modified membranes with photo-Fenton self-cleaning property for sustainable oil-in-water emulsion separation. Sep. Purif. Technol. 2021, $272,118893$. [CrossRef]

24. Le, K.H.; Nguyen, M.D.B.; Tran, L.D.; Nguyen Thi, H.P.; Van Tran, C.; Van Tran, K.; Nguyen Thi, H.P.; Dinh Thi, N.; Yoon, Y.S.; Nguyen, D.D.; et al. A novel antimicrobial ZnO nanoparticles-added polysaccharide edible coating for the preservation of postharvest avocado under ambient conditions. Prog. Org. Coat. 2021, 158, 106339. [CrossRef]

25. Choudhary, K.; Saini, R.; Upadhyay, G.K.; Purohit, L.P. Sustainable behavior of cauliflower like morphology of Y-doped ZnO:CdO nanocomposite thin films for $\mathrm{CO}_{2}$ gas sensing application at low operating temperature. J. Alloys Compd. 2021, 879, 160479. [CrossRef] 
26. Singh, M.; Ohji, T.; Asthana, R. Green and Sustainable Manufacturing of Advanced Material; Elsevier: Amsterdam, The Netherlands, 2016.

27. Wuebbles, D.J.; Fahey, D.W.; Hibbard, K.A.; DeAngelo, B.; Doherty, S.; Hayhoe, K.; Horton, R.; Kossin, J.P.; Taylor, P.C.; Waple, A.M.; et al. Executive Summary. Climate Science Special Report: Fourth National Climate Assessment; U.S. Global Change Research Program: Washington, DC, USA, 2017; Volume I.

28. Gottardo, S.; Mech, A.; Drbohlavová, J.; Małyska, A.; Bøwadt, S.; Riego Sintes, J.; Rauscher, H. Towards safe and sustainable innovation in nanotechnology: State-of-play for smart nanomaterials. NanoImpact 2021, 21, 100297. [CrossRef]

29. Sánchez Jiménez, A.; Puelles, R.; Pérez-Fernández, M.; Gómez-Fernández, P.; Barruetabeña, L.; Jacobsen, N.R.; Suarez-Merino, B.; Micheletti, C.; Manier, N.; Trouiller, B.; et al. Safe(r) by design implementation in the nanotechnology industry. NanoImpact 2020, 20, 100267. [CrossRef]

30. Fiameni, S.; Battiston, S.; Castellani, V.; Barison, S.; Armelao, L. Implementing sustainability in laboratory activities: A case study on aluminum titanium nitride based thin fi $\mathrm{lm}$ magnetron sputtering deposition onto commercial laminated steel. J. Clean. Prod. 2021, 285, 124869. [CrossRef]

31. Salieri, B.; Barruetabeña, L.; Rodríguez-Llopis, I.; Jacobsen, N.R.; Manier, N.; Trouiller, B.; Chapon, V.; Hadrup, N.; Jiménez, A.S.; Micheletti, C.; et al. Integrative approach in a safe by design context combining risk, life cycle and socio-economic assessment for safer and sustainable nanomaterials. NanoImpact 2021, 23, 100335. [CrossRef]

32. Zhang, P.; Liu, Z. On sustainable manufacturing of Cr-Ni alloy coatings by laser cladding and high-efficiency turning process chain and consequent corrosion resistance. J. Clean. Prod. 2017, 161, 676-687. [CrossRef]

33. Ma, M.; Han, A.; Zhang, Z.; Lian, Y.; Zhao, C.; Zhang, J. The role of Si on microstructure and high-temperature oxidation of $\mathrm{CoCr}_{2} \mathrm{FeNb}_{0.5} \mathrm{Ni}$ high-entropy alloy coating. Corros. Sci. 2021, 185, 109417. [CrossRef]

34. Fu, Y.; Huang, C.; Du, C.; Li, J.; Dai, C.; Luo, H.; Liu, Z.; Li, X. Evolution in microstructure, wear, corrosion, and tribocorrosion behavior of Mo-containing high-entropy alloy coatings fabricated by laser cladding. Corros. Sci. 2021, 191, 109727. [CrossRef]

35. $\mathrm{Gu}, \mathrm{Z}$; $\mathrm{Xi}$, S.; Sun, C. Microstructure and properties of laser cladding and $\mathrm{CoCr}_{2.5} \mathrm{FeNi}_{2}$ Tix high-entropy alloy composite coatings . J. Alloys Compd. 2020, 819, 152986. [CrossRef]

36. Jiao, H.; Song, W.; Chen, H.; Wang, M.; Jiao, S.; Fang, D. Sustainable recycling of titanium scraps and purity titanium production via molten salt electrolysis. J. Clean. Prod. 2020, 261, 121314. [CrossRef]

37. Peng, J.; Yuan, S.; Geng, H.; Zhang, X.; Zhang, M.; Xu, F.; Lin, D.; Gao, Y.; Wang, H. Robust and multifunctional superamphiphobic coating toward effective. Chem. Eng. J. 2022, 428, 131162. [CrossRef]

38. Pathak, S.; Saha, G.C. Development of sustainable cold spray coatings and 3D additive manufacturing components for repair/manufacturing applications: A critical review. Coatings 2017, 7, 122. [CrossRef]

39. Cirisano, F.; Ferrari, M. Superhydrophobicity and Durability in Recyclable Polymers Coating. Sustainability 2021, $13,8244$. [CrossRef]

40. Wang, Q.; Sun, G.; Tong, Q.; Yang, W.; Hao, W. Fluorine-free superhydrophobic coatings from polydimethylsiloxane for sustainable chemical engineering: Preparation methods and applications. Chem. Eng. J. 2021, 426, 130829. [CrossRef]

41. Wang, S.; Li, L.; Li, J.; Wang, J.; Pan, E.; Lu, J.; Zhang, Y.; Yang, J. Sustainable synthesis of highly water-selective ZSM-5 membrane by wet gel conversion. J. Memb. Sci. 2021, 635, 119431. [CrossRef]

42. Niu, J.; Wang, H.; Chen, J.; Chen, X.; Han, X.; Liu, H. Bio-inspired zwitterionic copolymers for antifouling surface and oil-water separation. Colloids Surf. A Physicochem. Eng. Asp. 2021, 626, 127016. [CrossRef]

43. Boillot, P.; Peultier, J. Use of stainless steels in the industry: Recent and future developments. Procedia Eng. 2014, 83, 309-321. [CrossRef]

44. Morral, F.R. Cobalt-Base Alloys In Aerospace. Sp. Congr. Proc. 1970, 3. Available online: https://commons.erau.edu/cgi/ viewcontent.cgi? article=3128\&context=space-congress-proceedings (accessed on 12 September 2021).

45. Konieczny, B.; Szczesio-Wlodarczyk, A.; Sokolowski, J.; Bociong, K. Challenges of co-cr alloy additive manufacturing methods in dentistry-the current state of knowledge (Systematic review). Materials 2020, 13, 3524. [CrossRef]

46. Ionita, D.; Pirvu, C.; Stoian, A.B.; Demetrescu, I. The Trends of TiZr Alloy Research as a Viable Alternative for Ti and Ti16 Zr Roxolid Dental Implants. Coatings 2020, 10, 422. [CrossRef]

47. Negrescu, A.M.; Necula, M.G.; Gebaur, A.; Golgovici, F.; Nica, C.; Curti, F.; Iovu, H.; Costache, M.; Cimpean, A. In vitro macrophage immunomodulation by poly( $\varepsilon$-caprolactone) based-coated AZ31 Mg Alloy. Int. J. Mol. Sci. 2021, 22, 909. [CrossRef] [PubMed]

48. Muralikrishna, P.V.S.; Kishore, P.S.; Ramanaiah, N.; Pathanjali, V.V.S.P.K. Nickel base alloy with metal matrix composite zirconium boride with inorganic coatings for high temperature environments. Mater. Today Proc. 2020, 39, 1287-1290. [CrossRef]

49. Zhang, Y.; Han, T.; Xiao, M.; Shen, Y. Effect of $\mathrm{Nb}$ content on microstructure and properties of laser cladding $\mathrm{FeNiCoCrTi}_{0.5} \mathrm{Nbx}$ high-entropy alloy coating. Optik 2019, 198, 163316. [CrossRef]

50. Tan, A.W.Y.; Lek, J.Y.; Sun, W.; Bhowmik, A.; Marinescu, I.; Buenconsejo, P.J.; Dong, Z.; Liu, E. Microstructure, mechanical and tribological properties of cold sprayed Ti6Al4V-CoCr composite coatings. Compos. Part B Eng. 2020, 202, 108280. [CrossRef]

51. Cheol Lee, G.; Noh, H.; Yeom, H.; Jo, H.; Kyun Kim, T.; Kim, M.; Sridharan, K.; Sun Park, H. Zirconium-silicide coating on zircaloy-4 substrate for accident tolerance: Effects on oxidation resistance and boiling. Ann. Nucl. Energy 2019, 126, 350-358. [CrossRef] 
52. Wang, C.; Li, J.; Wang, T.; Chai, L.; Deng, C.; Wang, Y.; Huang, Y. Microstructure and properties of pure titanium coating on Ti-6Al-4V alloy by laser cladding. Surf. Coat. Technol. 2021, 416, 127137. [CrossRef]

53. Kumar, A.M.; Yusuf, A.; Hussein, M.A.; Umoren, S.A.; Ramakrishna, S.; Saravanan, S. Preparation and characterization of Pectin/Polypyrrole based multifunctional coatings on TiNbZr alloy for orthopaedic applications. Carbohydr. Polym. 2020, 242, 116285. [CrossRef]

54. Liu, S.; Zhang, Z.; Zhang, J.; Qin, G.; Zhang, E. Construction of a $\mathrm{TiO}_{2} / \mathrm{Cu}_{2} \mathrm{O}$ multifunctional coating on Ti-Cu alloy and its influence on the cell compatibility and antibacterial properties. Surf. Coat. Technol. 2021, 421, 127438. [CrossRef]

55. Hassim, M.H.; Idris, M.H.; Yajid, M.A.M.; Samion, S. Mechanical and wear behaviour of nanostructure $\mathrm{TiO}_{2}-\mathrm{Ag}_{\mathrm{g}} \mathrm{coating}$ on cobalt chromium alloys by air plasma spray and high velocity oxy-fuel. J. Mater. Res. Technol. 2019, 8, 2290-2299. [CrossRef]

56. Singh, B.; Singh, G.; Sidhu, B.S. In vitro investigation of $\mathrm{Nb}-\mathrm{Ta}$ alloy coating deposited on CoCr alloy for biomedical implants. Surf. Coat. Technol. 2019, 377, 124932. [CrossRef]

57. Dinu, M.; Cojocaru, M.; Braic, V.; Tarcolea, M.; Braic, M.; Miculescu, F.; Vladescu, A.; Cotrut, C.M. Improvement of the tribological performance in corrosive environment of CoCr alloy by TiSiON coatings. Appl. Surf. Sci. 2015, 332, 295-299. [CrossRef]

58. Bansal, P.; Singh, G.; Sidhu, H.S. Investigation of corrosion behavior and surface properties of plasma sprayed HA/Sr reinforced coatings on CoCr alloys. Mater. Chem. Phys. 2020, 253, 123330. [CrossRef]

59. Olms, C.; Yahiaoui-Doktor, M.; Remmerbach, T.W. Contact allergies to dental materials. Swiss Dent. J. 2019, 129, 571-579.

60. Al-Imam, H.; Benetti, A.R.; Özhayat, E.B.; Pedersen, A.M.L.; Johansen, J.D.; Thyssen, J.P.; Jellesen, M.S.; Gotfredsen, K. Cobalt release and complications resulting from the use of dental prostheses. Contact Dermat. 2016, 75, 377-383. [CrossRef]

61. Zigante, M.; Rincic Mlinaric, M.; Kastelan, M.; Perkovic, V.; Trinajstic Zrinski, M.; Spalj, S. Symptoms of titanium and nickel allergic sensitization in orthodontic treatment. Prog. Orthod. 2020, 21, 1-7. [CrossRef] [PubMed]

62. Hostýnek, J.J.; Reagan, K.E.; Maibach, H.I. Nickel Allergic Hypersensitivity: Prevalence and Incidence by Country, Gender, Age, and Occupation. In Nickel and the Skin; CRC Press: Boca Raton, FL, USA, 2019; pp. 39-82.

63. Isik, M.; Avila, J.D.; Bandyopadhyay, A. Alumina and tricalcium phosphate added CoCr alloy for load-bearing implants. Addit. Manuf. 2020, 36, 101553. [CrossRef]

64. Castellanos, M.I.; Zenses, A.S.; Grau, A.; Rodríguez-Cabello, J.C.; Gil, F.J.; Manero, J.M.; Pegueroles, M. Biofunctionalization of REDV elastin-like recombinamers improves endothelialization on $\mathrm{CoCr}$ alloy surfaces for cardiovascular applications. Colloids Surf. B Biointerfaces 2015, 127, 22-32. [CrossRef] [PubMed]

65. Regulation (EU) 2017/745 of the European Parliament and of the Council of 5 April 2017 on Medical Devices, Amending Directive 2001/83/EC, Regulation (EC) No 178/2002 and Regulation (EC) No 1223/2009 and Repealing Council Directives 90/385/EEC and 93/42/EE. Off. J. Eur. Union. 2017. Available online: https://eur-lex.europa.eu/legal-content/EN/TXT/PDF/?uri=CELEX: 32017R0745 (accessed on 12 September 2021).

66. Vaicelyte, A.; Janssen, C.; Le Borgne, M.; Grosgogeat, B. Cobalt-Chromium Dental Alloys: Metal Exposures, Toxicological Risks, CMR Classification, and EU Regulatory Framework. Crystals 2020, 10, 1151. [CrossRef]

67. Padrós, R.; Giner-Tarrida, L.; Herrero-Climent, M.; Punset, M.; Gil, F.J. Corrosion resistance and ion release of dental prosthesis of COCR obtained by CAD-CAM milling, casting and laser sintering. Metals 2020, 10, 827. [CrossRef]

68. Hamza, G.; Sallam, H.; Eldwakhly, E. Effect of surface treatment of milled cobalt-chromium alloy on shear bond strength to porcelain. J. Arab Soc. Med. Res. 2019, 14, 113. [CrossRef]

69. Totea, G.; Ionita, D.; Demetrescu, I. Influence of Doping Ions on the Antibacterial Activity of Biomimetic Coating on CoCrMo Alloy. J. Bionic Eng. 2015, 12, 583-591. [CrossRef]

70. Băilă, D.-I.; Vițelaru, C.; Trușcă, R.; Constantin, L.R.; Păcurar, A.; Parau, C.A.; Păcurar, R. Thin Films Deposition of Ta $2 \mathrm{O}_{5}$ and ZnO by E-Gun Technology on Co-Cr Alloy Manufactured by Direct Metal Laser Sintering. Materials 2021, 14, 3666. [CrossRef]

71. Thakur, L.; Arora, N.; Jayaganthan, R.; Sood, R. An investigation on erosion behavior of HVOF sprayed WC-CoCr coatings. Appl. Surf. Sci. 2011, 258, 1225-1234. [CrossRef]

72. Lindahl, C.; Xia, W.; Engqvist, H.; Snis, A.; Lausmaa, J.; Palmquist, A. Biomimetic calcium phosphate coating of additively manufactured porous CoCr implants. Appl. Surf. Sci. 2015, 353, 40-47. [CrossRef]

73. Alvarez-Vera, M.; Hdz-García, H.M.; Díaz-Guillén, J.C.; Muñoz-Arroyo, R.; Acevedo-Davila, J.L.; Mtz-Enriquez, A.I.; Badillo, C.K.F. Tribological performance of Ti nanolayer coating post plasma nitriding treatment on Co based alloy. Wear 2021, 477, 1-9. [CrossRef]

74. Weng, W.; Biesiekierski, A.; Lin, J.; Li, Y.; Wen, C. Impact of rare earth elements on nanohardness and nanowear properties of beta-type Ti-24Nb-38Zr-2Mo alloy for medical applications. Materialia 2020, 12, 100772. [CrossRef]

75. Liao, X.; Zhang, J.; He, J.; Fan, W.; Yu, H.; Zhong, X.; Liu, Z. Development of cost-effective nanocrystalline multi-component (Ce,La, Y)-Fe-B permanent magnetic alloys containing no critical rare earth elements of Dy, Tb, Pr and Nd. J. Mater. Sci. Technol. 2021, 76, 215-221. [CrossRef]

76. Kim, D.H.; Lee, E.; Pak, C. Effect of rare-earth elements in Pd ternary alloy catalysts on activity toward oxygen reduction reaction. Catal. Today 2021, 359, 106-111. [CrossRef]

77. Yeh, J.W. Alloy design strategies and future trends in high-entropy alloys. Jom 2013, 65, 1759-1771. [CrossRef]

78. Miracle, D.B.; Miller, J.D.; Senkov, O.N.; Woodward, C.; Uchic, M.D.; Tiley, J. Exploration and development of high entropy alloys for structural applications. Entropy 2014, 16, 494-525. [CrossRef] 
79. Dobbelstein, H.; Gurevich, E.L.; George, E.P.; Ostendorf, A.; Laplanche, G. Laser metal deposition of compositionally graded TiZrNbTa refractory high-entropy alloys using elemental powder blends. Addit. Manuf. 2019, 25, 252-262. [CrossRef]

80. Miracle, D.B.; Senkov, O.N. A critical review of high entropy alloys and related concepts. Acta Mater. 2017, 122, 448-511. [CrossRef]

81. George, E.P.; Curtin, W.A.; Tasan, C.C. High entropy alloys: A focused review of mechanical properties and deformation mechanisms. Acta Mater. 2020, 188, 435-474. [CrossRef]

82. Brechtl, J.; Chen, S.; Lee, C.; Shi, Y.; Feng, R.; Xie, X.; Hamblin, D.; Coleman, A.M.; Straka, B.; Shortt, H.; et al. A review of the serrated-flow phenomenon and its role in the deformation behavior of high-entropy alloys. Metals 2020, 10, 1101. [CrossRef]

83. Ma, N.; Liu, S.; Liu, W.; Xie, L.; Wei, D.; Wang, L.; Li, L.; Zhao, B.; Wang, Y. Research Progress of Titanium-Based High Entropy Alloy: Methods, Properties, and Applications. Front. Bioeng. Biotechnol. 2020, 8, 1-18. [CrossRef]

84. Wang, X.R.; Wang, Z.Q.; Lin, T.S.; He, P. Mass transfer trends of AlCoCrFeNi high-entropy alloy coatings on TC11 substrate via electrospark-Computer numerical control deposition. J. Mater. Process. Technol. 2017, 241, 93-102. [CrossRef]

85. Yan, X.H.; Li, J.S.; Zhang, W.R.; Zhang, Y. A brief review of high-entropy films. Mater. Chem. Phys. 2018, 210, 12-19. [CrossRef]

86. Gu, Z.; Su, X.; Peng, W.; Guo, W.; Xi, S.; Zhang, X.; Tu, H.; Gao, Y.; Wu, H. An important improvement of strength and ductility on a new type of CoCr2.5FeNi2TiW0.5 high entropy alloys under two different protective gases by selective laser melting. J. Alloys Compd. 2021, 868. [CrossRef]

87. Liu, J.; Cui, Z.; Ma, D.; Lu, J.; Cui, Y.; Li, C.; Liu, W.; Hao, Z.; Hu, P.; Yao, M.; et al. Investigation of oxidation behaviors of coated Zircaloy as accident-tolerant fuel with CrAlN and CrAlSiN coatings in high-temperature steam. Corros. Sci. 2020, 175, 108896. [CrossRef]

88. Meng, Y.; Zeng, S.; Teng, Z.; Han, X.; Zhang, H. Control of the preferential orientation Cr coatings deposited on zircaloy substrates and study of their oxidation behavior. Thin Solid Films 2021, 730, 138699. [CrossRef]

89. Liu, J.; Hao, Z.; Cui, Z.; Ma, D.; Lu, J.; Cui, Y.; Li, C.; Liu, W.; Xie, S.; Hu, P.; et al. Oxidation behavior, thermal stability, and the coating/substrate interface evolution of CrN-coated Zircaloy under high-temperature steam. Corros. Sci. 2021, 185, 109416. [CrossRef]

90. Slobodyan, M. High-energy surface processing of zirconium alloys for fuel claddings of water-cooled nuclear reactors. Nucl. Eng. Des. 2021, 382, 111364. [CrossRef]

91. Umretiya, R.V.; Elward, B.; Lee, D.; Anderson, M.; Rebak, R.B.; Rojas, J.V. Mechanical and chemical properties of PVD and cold spray Cr-coatings on Zircaloy-4. J. Nucl. Mater. 2020, 541, 50-65. [CrossRef]

92. Song, L.; Huang, B.; Li, J.; Ma, X.; Liu, M.; Jiang, J.; Hu, Y. Effects of ion irradiation on Cr, CrN, and TiAlCrN coated Zircaloy-4 for accident tolerant fuel claddings. Ann. Nucl. Energy 2021, 156, 108206. [CrossRef]

93. Molaei, M.; Attarzadeh, N.; Fattah-alhosseini, A. Tailoring the biological response of zirconium implants using zirconia bioceramic coatings: A systematic review. J. Trace Elem. Med. Biol. 2021, 66, 126756. [CrossRef]

94. Nartita, R.; Ionita, D.; Demetrescu, I. A Combined Scientometric and Critical Approach in Reviewing TiZr Implant Alloys and Coating Performances. Coatings 2021, 11, 392. [CrossRef]

95. Fattah-alhosseini, A.; Chaharmahali, R.; Keshavarz, M.K.; Babaei, K. Surface characterization of bioceramic coatings on Zr and its alloys using plasma electrolytic oxidation (PEO): A review. Surf. Interfaces 2021, 25, 101283. [CrossRef]

96. Vidal, E.; Guillem-Marti, J.; Ginebra, M.; Combes, C.; Rupérez, E.; Rodriguez, D. Multifunctional homogeneous calcium phosphate coatings: Toward antibacterial and cell adhesive titanium scaffolds. Surf. Coat. Technol. 2021, 405, 126557. [CrossRef]

97. Mohanta, M.; Thirugnanam, A. Drug release studies of titanium-based polyethylene glycol coating as a multifunctional substrate. Mater. Today Proc. 2021. [CrossRef]

98. Wu, S.; Shen, X.; Chen, M.; Yie, K.H.R.; Zhou, Z.; Al-Baadani, M.A.; Fang, K.; Al-Bishari, A.M.; Deng, Z.; Liu, J.; et al. Multifunctional TaCu-nanotubes coated titanium for enhanced bacteriostatic, angiogenic and osteogenic properties. Mater. Sci. Eng. C 2021, 120, 111777. [CrossRef] [PubMed]

99. Demetrescu, I.; Dumitriu, C.; Totea, G.; Nica, C.; Dinischiotu, A.; Ionita, D. Zwitterionic Cysteine Drug Coating Influence in Functionalization of Implantable Ti50Zr Alloy for Antibacterial, Biocompatibility and Stability Properties. Pharmaceutics 2018, 10, 220. [CrossRef]

100. Bai, H.; Zhong, L.; Kang, L.; Liu, J.; Zhuang, W.; Lv, Z.; Xu, Y. A review on wear-resistant coating with high hardness and high toughness on the surface of titanium alloy. J. Alloys Compd. 2021, 882, 160645. [CrossRef]

101. Velumani, S.; Regmi, G.; Lee, M.; Castaneda, H.; Kuttolamadom, M.; Qian, X.; Kassiba, A. Engineered Zr/Zn/Ti oxide nanocomposite coatings for multifunctionality. Appl. Surf. Sci. 2021, 563, 150353. [CrossRef]

102. Atif, M.; Nawaz, R.; Zia, M.; Adrees, M.; Rizwan, M.; Ali, S.; Ahmad, S.; Tasleem, S. Ecotoxicology and Environmental Safety Synthesis, characterization and advanced sustainable applications of titanium dioxide nanoparticles: A review. Ecotoxicol. Environ. Saf. 2021, 212, 111978. [CrossRef]

103. Chen, J.; Lu, S.; Tan, L.; Etim, I.P.; Yang, K. Comparative study on effects of different coatings on biodegradable and wear properties of Mg-2Zn-1Gd-0.5Zr alloy. Surf. Coat. Technol. 2018, 352, 273-284. [CrossRef]

104. Fang, H.; Wang, C.; Zhou, S.; Li, G.; Tian, Y.; Suga, T. Exploration of the enhanced performances for silk fibroin/sodium alginate composite coatings on biodegradable Mg-Zn-Ca alloy. J. Magnes. Alloys 2020. [CrossRef] 
105. Istrate, B.; Rau, J.V.; Munteanu, C.; Antoniac, I.V.; Saceleanu, V. Properties and in vitro assessment of $\mathrm{ZrO}_{2}$-based coatings obtained by atmospheric plasma jet spraying on biodegradable Mg-Ca and Mg-Ca-Zr alloys. Ceram. Int. 2020, 46, 15897-15906. [CrossRef]

106. Li, J.; Chen, L.; Zhang, X.; Guan, S. Enhancing biocompatibility and corrosion resistance of biodegradable Mg-Zn-Y-Nd alloy by preparing PDA/HA coating for potential application of cardiovascular biomaterials. Mater. Sci. Eng. C 2020, $109,110607$. [CrossRef]

107. Tan, J.K.E.; Balan, P.; Birbilis, N. Advances in LDH coatings on Mg alloys for biomedical applications: A corrosion perspective. Appl. Clay Sci. 2021, 202, 105948. [CrossRef]

108. Xavier, J.R.; Raja Beryl, J.; Vinodhini, S.P. Novel multifunctional nanocomposites for superior barrier, hydrophobic and mechanical properties of Mg alloy in marine environment. Surf. Coat. Technol. 2021, 421, 127475. [CrossRef]

109. Fattah-alhosseini, A.; Chaharmahali, R. Enhancing corrosion and wear performance of PEO coatings on Mg alloys using graphene and graphene oxide additions: A review. FlatChem 2021, 27, 100241. [CrossRef]

110. Witecka, A.; Yamamoto, A.; Idaszek, J.; Chlanda, A.; Świeszkowski, W. Influence of biodegradable polymer coatings on corrosion, cytocompatibility and cell functionality of Mg-2.0Zn-0.98Mn magnesium alloy. Colloids Surf. B Biointerfaces 2016, 144, 284-292. [CrossRef]

111. Heimann, R.B. Magnesium alloys for biomedical application: Advanced corrosion control through surface coating. Surf. Coat. Technol. 2021, 405, 126521. [CrossRef]

112. Khalili, M.A.; Tamjid, E. Controlled biodegradation of magnesium alloy in physiological environment by metal organic framework nanocomposite coatings. Sci. Rep. 2021, 11, 1-13. [CrossRef]

113. Prakash, C.; Singh, S.; Pabla, B.S.; Uddin, M.S. Synthesis, characterization, corrosion and bioactivity investigation of nano-HA coating deposited on biodegradable Mg-Zn-Mn alloy. Surf. Coat. Technol. 2018, 346, 9-18. [CrossRef]

114. Zhang, Z.Q.; Yang, Y.X.; Li, J.A.; Zeng, R.C.; Guan, S.K. Advances in coatings on magnesium alloys for cardiovascular stents-A review. Bioact. Mater. 2021, 6, 4729-4757. [CrossRef] [PubMed]

115. Asadi, H.; Suganthan, B.; Ghalei, S.; Handa, H.; Ramasamy, R.P. A multifunctional polymeric coating incorporating lawsone with corrosion resistance and antibacterial activity for biomedical Mg alloys. Prog. Org. Coat. 2021, 153, 106157. [CrossRef]

116. Wang, S.; Wang, Y.; Chen, J.; Zou, Y.; Ouyang, J.; Jia, D.; Zhou, Y. Simple and scalable synthesis of super-repellent multilayer nanocomposite coating on $\mathrm{Mg}$ alloy with mechanochemical robustness, high-temperature endurance and electric protection. $J$. Magnes. Alloys 2021. [CrossRef]

117. Liu, X.; Zhang, T.C.; Zhang, Y.; Rao, J.; Yuan, S. A route for large-scale preparation of multifunctional superhydrophobic coating with electrochemically-modified kaolin for efficient corrosion protection of magnesium alloys. J. Magnes. Alloys 2021. [CrossRef]

118. Ouyang, Y.; Li, L.X.; Xie, Z.H.; Tang, L.; Wang, F.; Zhong, C.J. A self-healing coating based on facile pH-responsive nanocontainers for corrosion protection of magnesium alloy. J. Magnes. Alloys 2020, 15-18. [CrossRef]

119. Xue, K.; Liang, L.X.; Cheng, S.C.; Liu, H.P.; Cui, L.Y.; Zeng, R.C.; Li, S.Q.; Wang, Z.L. Corrosion resistance, antibacterial activity and drug release of ciprofloxacin-loaded micro-arc oxidation/silane coating on magnesium alloy AZ31. Prog. Org. Coat. 2021, 158, 106357. [CrossRef]

120. Shi, H.; Hong, L.; Pan, K.; Wei, W.; Liu, X.; Li, X. Biodegradable polyacrylate copolymer coating for bio-functional magnesium alloy. Prog. Org. Coat. 2021, 159, 106422. [CrossRef]

121. Li, J.; Wang, S.; Sheng, Y.; Liu, C.; Xue, Z.; Tong, P.; Guan, S. Designing HA/PEI nanoparticle composite coating on biodegradable $\mathrm{Mg}-\mathrm{Zn}-\mathrm{Y}-\mathrm{Nd}$ alloy to direct cardiovascular cells fate. Smart Mater. Med. 2021, 2, 124-133. [CrossRef]

122. Kang, M.H.; Cheon, K.H.; Jo, K.I.; Ahn, J.H.; Kim, H.E.; Jung, H.D.; Jang, T.S. An asymmetric surface coating strategy for improved corrosion resistance and vascular compatibility of magnesium alloy stents. Mater. Des. 2020, 196, 109182. [CrossRef]

123. Bakhsheshi-Rad, H.R.; Ismail, A.F.; Aziz, M.; Hadisi, Z.; Omidi, M.; Chen, X. Antibacterial activity and corrosion resistance of $\mathrm{Ta}_{2} \mathrm{O}_{5}$ thin film and electrospun $\mathrm{PCL} / \mathrm{MgO}-\mathrm{Ag}$ nanofiber coatings on biodegradable $\mathrm{Mg}$ alloy implants. Ceram. Int. 2019, 45, 11883-11892. [CrossRef]

124. Song, Y.; Shan, D.; Han, E.H. A novel biodegradable nicotinic acid/calcium phosphate composite coating on Mg-3Zn alloy. Mater Sci. Eng. C 2013, 33, 78-84. [CrossRef]

125. Liu, Y.; Zhang, Y.; Wang, Y.-L.; Tian, Y.-Q.; Chen, L.-S. Research Progress on Surface Protective Coatings of Biomedical Degradable Magnesium alloys. J. Alloys Compd. 2021, 885, 161001. [CrossRef]

126. Shahri, Z.; Allahkaram, S.R.; Soltani, R.; Jafari, H. Study on corrosion behavior of nano-structured coatings developed on biodegradable as cast Mg-Zn-Ca alloy by plasma electrolyte oxidation. Surf. Coat. Technol. 2018, 347, 225-234. [CrossRef]

127. Bakhsheshi-Rad, H.R.; Hamzah, E.; Ebrahimi-Kahrizsangi, R.; Daroonparvar, M.; Medraj, M. Fabrication and characterization of hydrophobic microarc oxidation/poly-lactic acid duplex coating on biodegradable Mg-Ca alloy for corrosion protection. Vacuum 2016, 125, 185-188. [CrossRef]

128. Ly, X.; Yang, S.; Nguyen, T. Effect of equal channel angular pressing as the pretreatment on microstructure and corrosion behavior of micro-arc oxidation (MAO) composite coating on biodegradable Mg-Zn-Ca alloy. Surf. Coat. Technol. 2020, $395,125923$. [CrossRef]

129. Prakash, C.; Singh, S.; Singh, M.; Verma, K.; Chaudhary, B.; Singh, S. Multi-objective particle swarm optimization of EDM parameters to deposit HA-coating on biodegradable Mg-alloy. Vacuum 2018, 158, 180-190. [CrossRef] 
130. Saji, V.S. Recent progress in superhydrophobic and superamphiphobic coatings for magnesium and its alloys. J. Magnes. Alloys 2021, 9, 748-778. [CrossRef]

131. Yazici, M.; Gulec, A.E.; Gurbuz, M.; Gencer, Y.; Tarakci, M. Biodegradability and antibacterial properties of MAO coatings formed on Mg-Sr-Ca alloys in an electrolyte containing Ag doped hydroxyapatite. Thin Solid Films 2017, 644, 92-98. [CrossRef]

132. Ionita, D.; Dilea, M.; Titorencu, I.; Demetrescu, I. Merit and demerit effects of silver nanoparticles in the bioperformance of an electrodeposited hydroxyapatite: Nanosilver composite coating. J. Nanopart. Res. 2012, 14. [CrossRef]

133. Wright, P.F. Potential risks and benefits of nanotechnology: Perceptions of risk in sunscreens. Med. J. Aust. 2016, 204, 369-370. [CrossRef] [PubMed]

134. Vardaki, M.; Pantazi, A.; Demetrescu, I.; Enachescu, M. Assessing the Functional Properties of TiZr Nanotubular Structures for Biomedical Applications, through Nano-Scratch Tests and Adhesion Force Maps. Molecules 2021, 26, 900. [CrossRef] [PubMed]

135. Macak, J.M.; Hildebrand, H.; Marten-Jahns, U.; Schmuki, P. Mechanistic aspects and growth of large diameter self-organized $\mathrm{TiO}_{2}$ nanotubes. J. Electroanal. Chem. 2008, 621, 254-266. [CrossRef]

136. Ivanova, A.A.; Surmeneva, M.A.; Shugurov, V.V.; Koval, N.N.; Shulepov, I.A.; Surmenev, R.A. Physico-mechanical properties of Ti-Zr coatings fabricated via ion-assisted arc-plasma deposition. Vacuum 2018, 149, 129-133. [CrossRef]

137. Montemor, M.F. Functional and smart coatings for corrosion protection: A review of recent advances. Surf. Coat. Technol. 2014, 258, 17-37. [CrossRef]

138. Presuel-Moreno, F.; Jakab, M.A.; Tailleart, N.; Goldman, M.; Scully, J.R. Corrosion-resistant metallic coatings. Mater. Today 2008, 11, 14-23. [CrossRef]

139. Zheludkevich, M.L.; Salvado, I.M.; Ferreira, M.G.S. Sol-gel coatings for corrosion protection of metals. J. Mater. Chem. 2005, 15, 5099-5111. [CrossRef]

140. Dennis, R.V.; Patil, V.; Andrews, J.L.; Aldinger, J.P.; Yadav, G.D.; Banerjee, S. Hybrid nanostructured coatings for corrosion protection of base metals: A sustainability perspective. Mater. Res. Express 2015, 2, 32001. [CrossRef]

141. Metroke, T.L.; Parkhill, R.L.; Knobbe, E.T. Passivation of metal alloys using sol-gel-derived materials-A review. Prog. Org. Coat. 2001, 41, 233-238. [CrossRef]

142. Hughes, A.E.; Cole, I.S.; Muster, T.H.; Varley, R.J. Designing green, self-healing coatings for metal protection. NPG Asia Mater. 2010, 2, 143-151. [CrossRef]

143. Grigoriev, D.; Akcakayiran, D.; Schenderlein, M.; Shchukin, D. Protective Organic Coatings with Anticorrosive and Other Feedback-Active Features: Micro- and Nanocontainers-Based Approach. Corrosion 2014, 70, 446-463. [CrossRef]

144. Mîndroiu, M.; Pîrvu, C.; Cîmpean, A.; Demetrescu, I. Corrosion and biocompatibility of PPy/PEG coating electrodeposited on Ti6Al7Nb alloy. Mater. Corros. 2013, 64, 926-931. [CrossRef]

145. Gaur, S.; Khanna, A.S. Functional Coatings by Incorporating Nanoparticles. Nano Res. Appl. 2015, 1, 1-8.

146. Abdus Samad, U.; Alam, M.A.; Anis, A.; Sherif, E.-S.M.; Al-Mayman, S.I.; Al-Zahrani, S.M. Effect of Incorporated ZnO Nanoparticles on the Corrosion Performance of $\mathrm{SiO}_{2}$ Nanoparticle-Based Mechanically Robust Epoxy Coatings. Materials 2020, 13, 3767. [CrossRef] [PubMed]

147. Ramezanzadeh, M.; Ramezanzadeh, B.; Mahdavian, M.; Bahlakeh, G. Development of metal-organic framework (MOF) decorated graphene oxide nanoplatforms for anti-corrosion epoxy coatings. Carbon 2020, 161, 231-251. [CrossRef]

148. Verma, P.; Anoop, S.; Sasidhara Rao, V.; Sharma, A.K.; Uma Rani, R. Multiwalled carbon nanotube-poly vinyl alcohol nanocomposite multifunctional coatings on aerospace alloys. Mater. Today Proc. 2018, 5, 21205-21216. [CrossRef]

149. Farag, A.A. Applications of nanomaterials in corrosion protection coatings and inhibitors. Corros. Rev. 2020, 1-20. [CrossRef]

150. Dharmaraj, B.M.; Subramani, R.; Dhanaraj, G.; Louis, K. Multifunctional halloysite nanotube based composite coatings on titanium as metal implant for orthopedic applications. Compos. Part C Open Access 2020, 3, 100077. [CrossRef]

151. Xosé Fernández Sánchez-Romate, X.; Jiménez Suárez, A.; González Prolongo, S. Smart Coatings with Carbon Nanoparticles. In 21st Century Surface Science-A Handbook; IntechOpen: London, UK, 2020.

152. Othman, N.H.; Che Ismail, M.; Mustapha, M.; Sallih, N.; Kee, K.E.; Ahmad Jaal, R. Graphene-based polymer nanocomposites as barrier coatings for corrosion protection. Prog. Org. Coat. 2019, 135, 82-99. [CrossRef]

153. Kumar, S.S.A.; Bashir, S.; Ramesh, K.; Ramesh, S. New perspectives on Graphene/Graphene oxide based polymer nanocomposites for corrosion applications: The relevance of the Graphene/Polymer barrier coatings. Prog. Org. Coat. 2021, 154, 106215. [CrossRef]

154. Kim, S.; Le, T.H.; Park, C.S.; Park, G.; Kim, K.H.; Kim, S.; Kwon, O.S.; Lim, G.T.; Yoon, H. A solution-processable, nanostructured, and conductive graphene/polyaniline hybrid coating for metal-corrosion protection and monitoring. Sci. Rep. 2017, 7, 1-9. [CrossRef]

155. Murugan, N.; Murugan, C.; Sundramoorthy, A.K. In vitro and in vivo characterization of mineralized hydroxyapatite/ polycaprolactone-graphene oxide based bioactive multifunctional coating on Ti alloy for bone implant applications. Arab. J. Chem. 2018, 11, 959-969. [CrossRef]

156. Chen, C.; Qiu, S.; Cui, M.; Qin, S.; Yan, G.; Zhao, H.; Wang, L.; Xue, Q. Achieving high performance corrosion and wear resistant epoxy coatings via incorporation of noncovalent functionalized graphene. Carbon 2017, 114, 356-366. [CrossRef]

157. Bibber, J.W. Chromium-Free Conversion Coatings for Zinc and Its Alloys. J. Appl. Surf. Finish. 2007, 2, $273-275$.

158. Bierwagen, G.; Brown, R.; Battocchi, D.; Hayes, S. Active metal-based corrosion protective coating systems for aircraft requiring no-chromate pretreatment. Prog. Org. Coat. 2010, 68, 48-61. [CrossRef] 
159. Dennis, R.V.; Viyannalage, L.T.; Aldinger, J.P.; Rout, T.K.; Banerjee, S. Nanostructured magnesium composite coatings for corrosion protection of low-alloy steels. Ind. Eng. Chem. Res. 2014, 53, 18873-18883. [CrossRef]

160. Dennis, R.V.; Fleer, N.A.; Davidson, R.D.; Banerjee, S. Graphene Coatings for the Corrosion Protection of Base Metals. In Graphene Technology: From Laboratory to Fabrication; Wiley-VCH Verlag GmbH \& Co. KGaA: Weinheim, Germany, 2016; pp. 155-176. ISBN 9783527687541.

161. Chen, L.; Duan, Y.; Cui, M.; Huang, R.; Su, R.; Qi, W.; He, Z. Biomimetic surface coatings for marine antifouling: Natural antifoulants, synthetic polymers and surface microtopography. Sci. Total Environ. 2021, 766, 144469. [CrossRef] [PubMed]

162. Cheng, Z.; Han, H.; Wang, F.; Yan, Y.; Shi, X.; Liang, H.; Zhang, X.; Shuai, Y. Efficient radiative cooling coating with biomimetic human skin wrinkle structure. Nano Energy 2021, 89, 106377. [CrossRef]

163. Liu, D.; Ma, Z.; Zhao, H.; Ren, L.; Zhang, W. Nano-indentation of biomimetic artificial bone material based on porous Ti6Al4V substrate with $\mathrm{Fe}_{22} \mathrm{Co}_{22} \mathrm{Ni}_{22} \mathrm{Ti}_{22} \mathrm{Al}_{12}$ high entropy alloy coating. Mater. Today Commun. 2021, 28, 102659. [CrossRef]

164. Sartori, M.; Graziani, G.; Sassoni, E.; Pagani, S.; Boi, M.; Maltarello, M.C.; Baldini, N.; Fini, M. Nanostructure and biomimetics orchestrate mesenchymal stromal cell differentiation: An in vitro bioactivity study on new coatings for orthopedic applications. Mater. Sci. Eng. C 2021, 123, 112031. [CrossRef]

165. Lv, D.; Li, P.; Zhou, L.; Wang, R.; Chen, H.; Li, X.; Zhao, Y.; Wang, J.; Huang, N. Synthesis, evaluation of phospholipid biomimetic polycarbonate for potential cardiovascular stents coating. React. Funct. Polym. 2021, 163, 104897. [CrossRef]

166. Rahman, M.; Dutta, N.K.; Choudhury, N.R. Microroughness induced biomimetic coating for biodegradation control of magnesium. Mater. Sci. Eng. C 2021, 121, 111811. [CrossRef]

167. Wu, Y.; Xu, G.; Wang, T.; Liu, K.; Lu, J.; Wang, D. Preparation of biomimetic hair-like composite coatings with water-collecting and superamphiphobic properties. Prog. Org. Coat. 2021, 158, 106372. [CrossRef]

168. Zhang, W.; Fan, S.; Wang, Y.; Lang, X.; Li, G. Preparation and performance of biomimetic superhydrophobic coating on X80 pipeline steel for inhibition of hydrate adhesion. Chem. Eng. J. 2021, 419, 129651. [CrossRef]

169. Rajan, R.A.; Ngo, C.V.; Yang, J.; Liu, Y.; Rao, K.S.; Guo, C. Femtosecond and picosecond laser fabrication for long-term superhydrophilic metal surfaces. Opt. Laser Technol. 2021, 143, 107241. [CrossRef]

170. Tran, N.G.; Chun, D.M. Green manufacturing of extreme wettability contrast surfaces with superhydrophilic and superhydrophobic patterns on aluminum. J. Mater. Process. Technol. 2021, 297, 117245. [CrossRef]

171. Goharshenas Moghadam, S.; Parsimehr, H.; Ehsani, A. Multifunctional superhydrophobic surfaces. Adv. Colloid Interface Sci. 2021, 290, 102397. [CrossRef]

172. Stoian, A.B.; Vardaki, M.; Ionita, D.; Enachescu, M.; Prodana, M.; Brancoveanu, O.; Demetrescu, I. Nanopores and nanotubes ceramic oxides elaborated on titanium alloy with zirconium by changing anodization potentials. Ceram. Int. 2018, 44, 7026-7033. [CrossRef]

173. Bauer, S.; Park, J.; Faltenbacher, J.; Berger, S.; Von Der Mark, K.; Schmuki, P. Size selective behavior of mesenchymal stem cells on $\mathrm{ZrO}_{2}$ and $\mathrm{TiO}_{2}$ nanotube arrays. Integr. Biol. 2009, 1, 525-532. [CrossRef]

174. Ion, R.; Stoian, A.B.; Dumitriu, C.; Grigorescu, S.; Mazare, A.; Cimpean, A.; Demetrescu, I.; Schmuki, P. Nanochannels formed on TiZr alloy improve biological response. Acta Biomater. 2015, 24, 370-377. [CrossRef] [PubMed]

175. Ion, R.; Mazare, A.; Dumitriu, C.; Pirvu, C.; Schmuki, P.; Cimpean, A. Nanochannelar topography positively modulates osteoblast differentiation and inhibits osteoclastogenesis. Coatings 2018, 8, 294. [CrossRef]

176. Guo, Y.-P.; Guan, J.-J.; Yang, J.; Wang, Y.; Zhang, C.-Q.; Ke, Q.-F. Hybrid nanostructured hydroxyapatite-chitosan composite scaffold: Bioinspired fabrication, mechanical properties and biological properties. J. Mater. Chem. B 2015, 3, 4679-4689. [CrossRef]

177. Ionita, D.; Vardaki, M.; Stan, M.S.; Dinischiotu, A.; Demetrescu, I. Enhance Stability and in vitro Cell Response to a Bioinspired Coating on Zr Alloy with Increasing Chitosan Content. J. Bionic Eng. 2017, 14, 459-467. [CrossRef]

178. Li, L.; Zhang, G.; Su, Z. One-Step Assembly of Phytic Acid Metal Complexes for Superhydrophilic Coatings. Angew. Chem. Int. Ed. 2016, 55, 9093-9096. [CrossRef]

179. Ding, L.; Wang, Y.; Xiong, J.; Lu, H.; Zeng, M.; Zhu, P.; Ma, H. Plant-inspired layer-by-layer self-assembly of super-hydrophobic coating for oil spill cleanup. Polymers 2019, 11, 2047. [CrossRef] [PubMed]

180. Milne, A.J.B.; Amirfazli, A. The Cassie equation: How it is meant to be used. Adv. Colloid Interface Sci. 2012, 170, 48-55. [CrossRef]

181. Iacono, S.T.; Jennings, A.R. Recent Studies on Fluorinated Silica Nanometer-Sized Particles. Nanomaterials 2019, 9, 684. [CrossRef]

182. Lettieri, M.; Masieri, M.; Frigione, M. Novel nano-filled coatings for the protection of built heritage stone surfaces. Nanomaterials 2021, 11, 301. [CrossRef] [PubMed]

183. Jiaqiang, E.; Jin, Y.; Deng, Y.; Zuo, W.; Zhao, X.; Han, D.; Peng, Q.; Zhang, Z. Wetting Models and Working Mechanisms of Typical Surfaces Existing in Nature and Their Application on Superhydrophobic Surfaces: A Review. Adv. Mater. Interfaces 2018, 5, 1-39. [CrossRef]

184. Shchukina, E.; Wang, H.; Shchukin, D.G. Nanocontainer-based self-healing coatings: Current progress and future perspectives Chem. Commun. 2019, 55, 3859-3867. [CrossRef] [PubMed]

185. Mendoza-Fong, J.R.; García-Alcaraz, J.L.; Díaz-Reza, J.R.; Jiménez-Macías, E.; Blanco-Fernández, J. The role of green attributes in production processes as well as their impact on operational, commercial, and economic benefits. Sustainability 2019, $11,1294$. [CrossRef] 